Risk-Adjustment for Swedish In-Hospital Trauma Mortality using International Classification of disease Injury Severity Score (ICISS): issues with description and methods

Robert Larsen

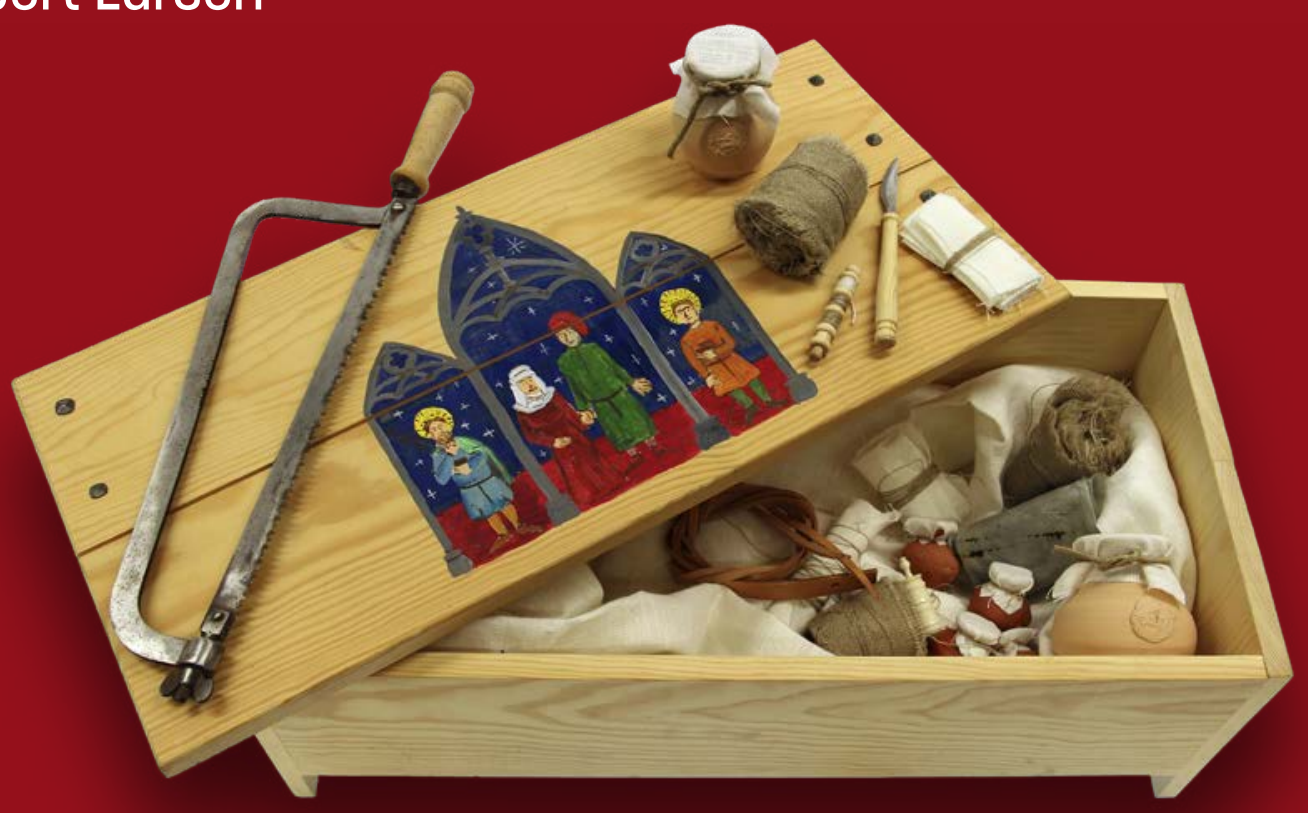


Linköping University Medical Dissertation

No. 1660

Risk-Adjustment for Swedish In-Hospital Trauma Mortality using International Classification of disease Injury Severity Score (ICISS): issues with description and methods

Robert Larsen

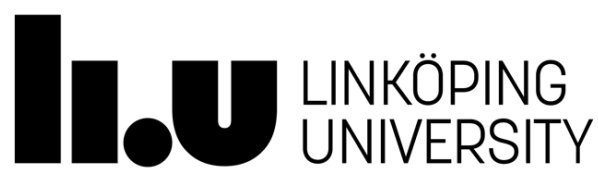

Department of Clinical and Experimental Medicine,

Division of Surgery, Orthopedics and Oncology

The Faculty of Medicine and Health Sciences

Linköpings universitet, SE-581 83 Linköping, Sweden

Linköping 2019 


\title{
Risk-Adjustment for Swedish In-Hospital Trauma Mortality using International Classification of disease Injury Severity Score (ICISS): issues with description and methods
}

\author{
By \\ Robert Larsen \\ February 2019 \\ ISBN 978-91-7685-140-1 \\ Linköping University Medical Dissertation \\ No. 1660 \\ ISSN 0345-0082
}

Keywords: Trauma, Injury, Epidemiology, Risk-adjustment, ICISS

Department of Clinical and Experimental Medicine

Linköpings universitet

SE-581 83 Linköping, Sweden 
To Hanna and Vidar 
Supervisor

Co-supervisors

Faculty opponent

External expert in the examination board

Examination board
Professor Folke Sjöberg MD, PhD

IKE, Linköping University, Sweden

\section{Ingrid Steinvall RN, PhD}

IKE, Linköping University, Sweden

Senior Lecturer Mats Fredrikson PhD

IKE, Linköping University, Sweden

Associate Professor Sten Walther MD, PhD

IMH, Linköping University, Sweden

Professor Eldar Søreide MD, PhD

Dept of Clinical Medicine, Bergen University, Norway

Associate Professor Lovisa Strömmer MD, PhD

Clintec, Karolinska Institutet, Sweden

Professor Chris Anderson MD, PhD

IKE, Linköping University, Sweden

Professor Oliver Gimm MD, PhD

IKE, Linköping University, Sweden

(C) Robert Larsen, 2019

Printed in Sweden by LiU-Tryck, Linköping 2019.

Photographer Marianne Fransson

ISSN 0345-0082

ISBN 978-91-7685-140-1 


\section{ABSTRACT}

\section{Introduction}

Different methods have been used to describe the epidemiology of trauma with varying results. Crude mortality outcome data differ significantly from risk-adjusted information. A previous standard method for risk-adjustment in trauma was the Injury Severity Score (ISS), although it has several shortcomings. In this thesis I examine Swedish injury statistics from an epidemiological perspective using crude and risk-adjusted mortality, and to adjust for injury I used the International Classification of disease Injury Severity Score (ICISS). The groups of most lethal injuries (fall, traffic, and assault) were examined separately using an ICISS mortality prediction model that focused particularly on the effects on the prediction of mortality by adding coexisting conditions (comorbidity) to it. Differences in mortality between the sexes and changes over time were tested separately.

\section{Material and Methods}

Data from all patients with ICD-10 based diagnoses of injury (ICD-10: V01 to Y36) in the Swedish National Patient Registry and Cause of Death Registry were collected from 1999 to 2012 and used for assessment of mortality and comorbidity. A subgroup (patients in hospital) from 2001-2011 were selected as the study group. Their injuries were in the subgroups of falls, traffic, and assaults, and are the focus of this thesis. Mortality within 30 days of injury was used as the endpoint. The severity of injury was adjusted for using the ICISS, which was first described by Osler et al. The model was also adjusted for age, sex, and comorbidities.

\section{Results}

The study group comprised 815846 patients (of whom 17721 died). There was a decrease over time in injuries caused by falls and traffic (coefficient $-4.71, \mathrm{p}=0.047$ and coefficient -5.37, $\mathrm{p}<0.001$ ), whereas there was no change in assault-related injuries/100 000 inhabitants. The risk-adjusted 30-day mortality showed a decrease in injuries related to traffic and assault (OR 0.95, $\mathrm{p}<0.001$ and OR 0.93, $\mathrm{p}=0.022$ ) whereas for falls it remained unchanged. There was also a risk-adjusted survival benefit for women, which increased with increasing age. Adjusting for comorbidities made the prediction of 30-day mortality by the ICISS model better (accuracy, calibration, and discrimination). However, most of this effect was found to be the result of the other characteristics of the fall related injury group (they were older, and had more coexisting conditions).

\section{Conclusion}

During a 10-year period, there has been a significant overall decrease in crude as well as risk-adjusted mortality for these three injury groups combined. Within these groups there is a clear, risk-adjusted, female survival advantage. The ICISS model for the prediction of mortality improves when comorbidities are added, but this effect is minor and seen mainly among the injuries caused by falls, where comorbidity is significant. The ICISS method was a valuable adjunct in the investigation of data on Swedish mortality after injury that has been gathered from health care registry data. 


\section{SAMMANFATTNING PÅ SVENSKA}

\section{Introduktion}

Olika metoder har använts för att beskriva trauma, alla med varierande resultat. Riskjusterad respektive icke-justerad data skiljer sig markant åt. En metod som oftast används för riskjustering i traumasammanhang är Injury Severity Score (ISS) som tyvärr är belastad med ett antal praktiska tillkortakommande. I denna avhandling har jag undersökt de skadade i Sverige från ett epidemiologiskt perspektiv med både justerad och icke riskjusterad mortalitet. För att kunna justera för skadan använde jag International Classification of disease Injury Severity Score (ICISS). De dödligaste skademekanismerna i Sverige (fall, trafik och övergrepp) analyserades för sig med hjälp av en mortalitetsjusterad modell baserad på ICISS som fokuserade särskilt på mortalitetseffekterna av att lägga till tidigare sjukdomar (komorbiditet) i modellen. Skillnader i dödlighet mellan de olika könen samt förändringar över tid undersöktes.

\section{Material och Metod}

Information om alla patienter med en skadekod från ICD-10 systemet (ICD10: V01-Y36) i slutenvårdsregistret eller dödsorsaksregistrets under åren 1999-2012 samlades in för att användas för att kunna utvärdera mortalitet och komorbiditet. En undergrupp av sjukhusinlagda patienter från 2001-2011 valdes sedan som primär studiegrupp. De som i denna grupp hade drabbats av fall-, trafik- eller övergrepps-relaterade skador är det denna avhandling fokuserar på. Som mätpunkt (endpoint) användes avliden inom 30 dagar från skadan. Skadans allvarlighetsgrad bedömdes med ICISS som Osler var först att beskriva. Modellen justerades även för ålder, kön och komorbiditet.

\section{Resultat}

Studiegruppen innehöll 815846 patienter (av vilka 17721 avled). I gruppen med falloch trafik-relaterade skador var det en ren minskning över studietiden (koefficienten $-4,71$ med ett $p=0,047$ och med en koefficient på $-5,37$ med ett $p<0,001)$, medans $i$ övergreppsrelaterade skador kunde jag inte hitta någon minskning per 100000 invånare. Den riskjusterade 30-dagars dödligheten hade en minskning $i$ trafik- och övergreppsrelaterade skador (OR 0,95 med ett $\mathrm{p}<0,001$ respektive OR 0,93 med ett $\mathrm{p}=0,022)$ men ingen minskning $\mathrm{i}$ fallrelaterade skador sågs. Riskjusterat gick det också att hitta en överlevnadsfördel för kvinnor, vilken ökade med ålder. När jag justerade för komorbiditeter blev prediktionsmodellen för ICISS med 30-dagars dödlighet bättre (detta gällde både precision, kalibrering och diskriminering). Det bör dock nämnas att det mesta av förbättringen vid eftergranskning var beroende på fall gruppens demografi (högre ålder och mer komorbiditeter).

\section{Konklusion}

Under denna tio-årsperiod har dödligheten minskat för dessa grupper, både riskjusterat och icke justerat. Inom dessa grupper finns en tydlig riskjusterad överlevnadsfördel för kvinnor. ICISS-modellen blir bättre på att förutspå 30-dagars dödlighet när man lägger till komorbiditet, men effekten är att betrakta som en mindre effekt och ses tydligast $\mathrm{i}$ fallrelaterade skador (där ålder och komorbiditet är högre). Metoden med ICISS är en värdefull metod för att undersöka stora datamaterial och dödlighet i stora grupper $\mathrm{i}$ Sverige. Detta kan göras med redan insamlade data i sjukvårdsregistren. 


\section{TABLE OF CONTENT}

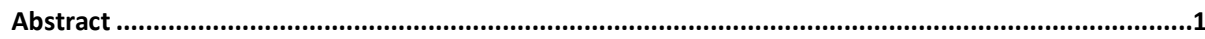

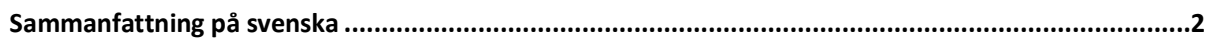

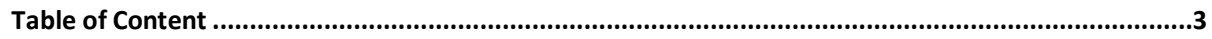

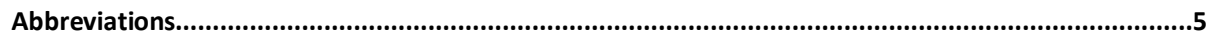

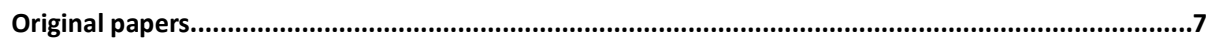

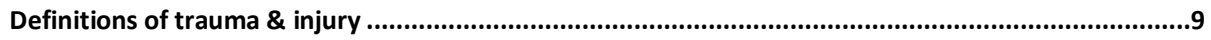

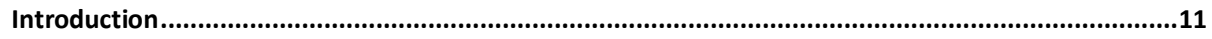

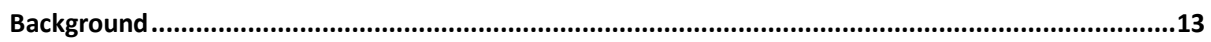

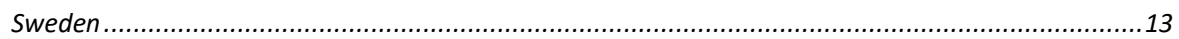

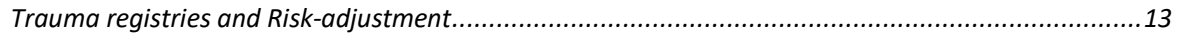

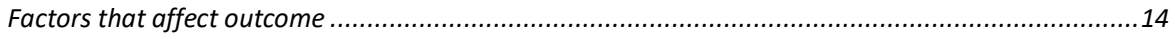

Definition of the different phases and mechanisms involved in injury and trauma .........................15

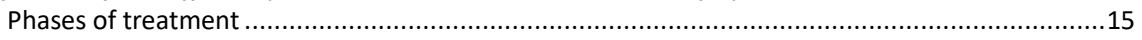

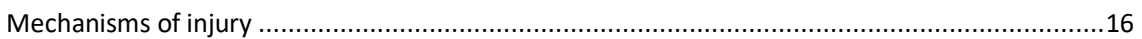

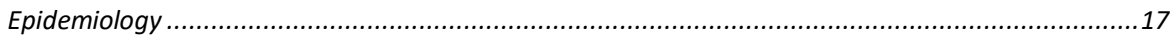

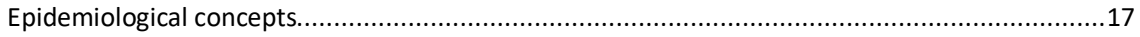

Comorbidity or cause, association or causation? ............................................................. 18

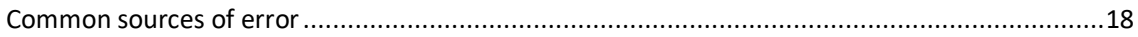

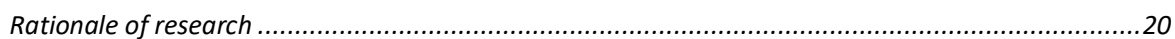

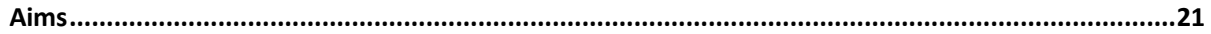

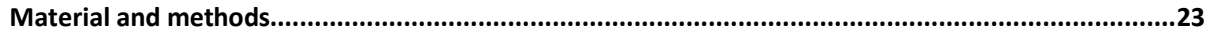

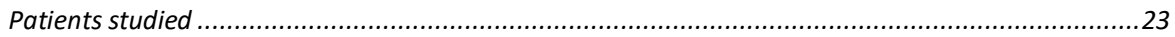

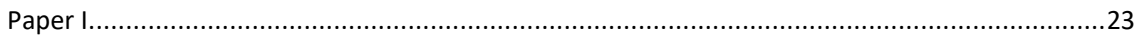

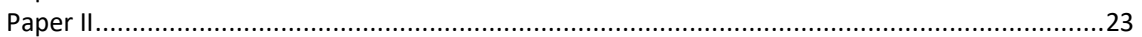

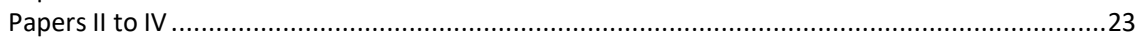

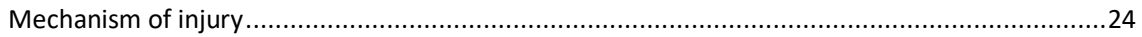

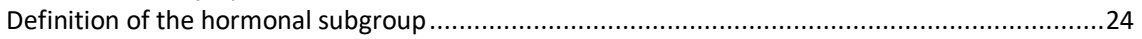

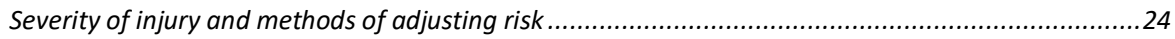

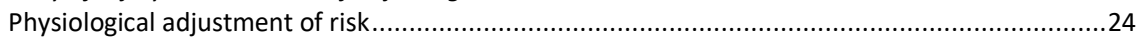

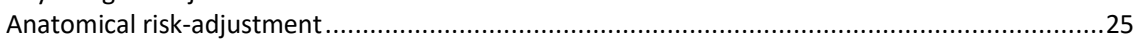

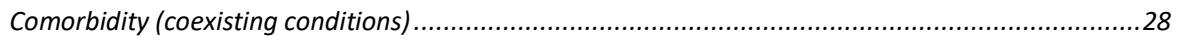

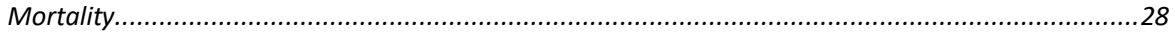

Age

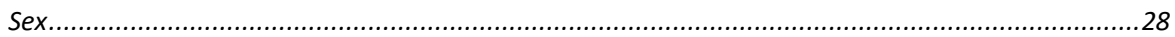

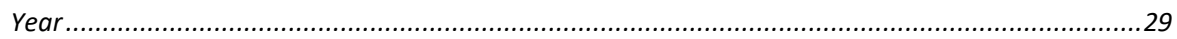

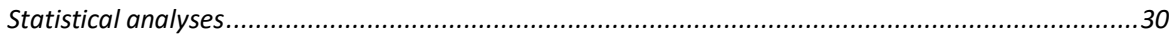

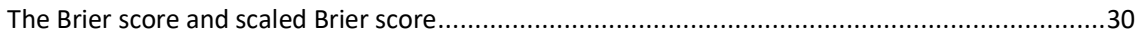

Cox's calibration and Hosmer Lemeshow's goodness of fit ................................................ 30

Coefficient of correlation and coefficient of determination .................................................. 31 


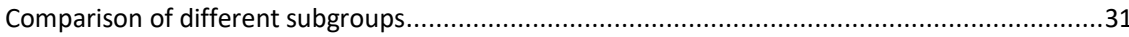

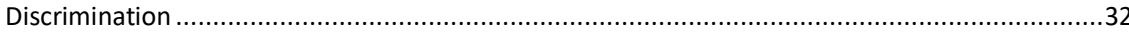

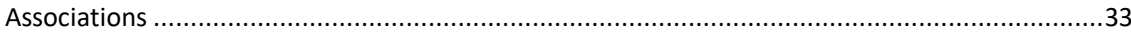

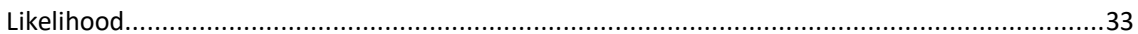

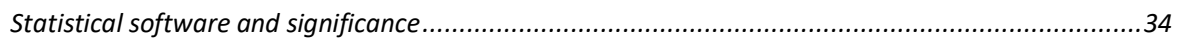

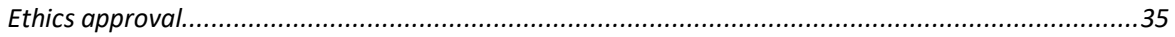

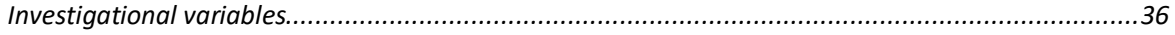

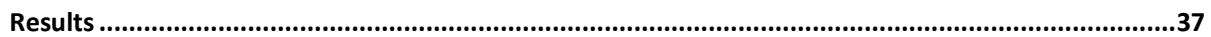

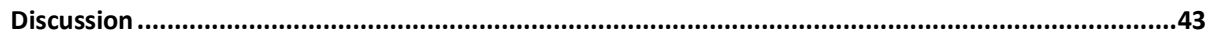

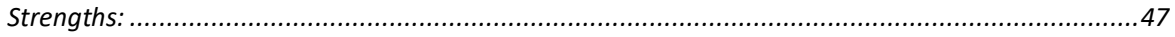

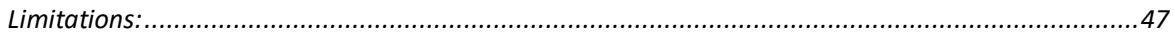

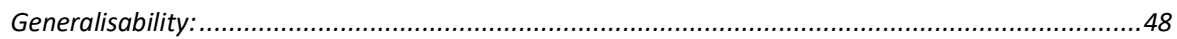

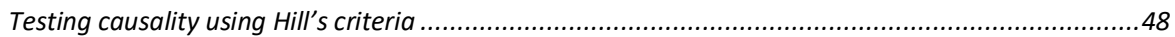

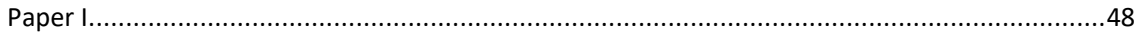

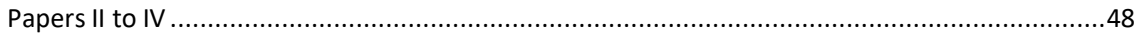

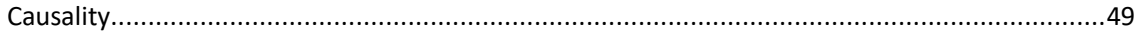

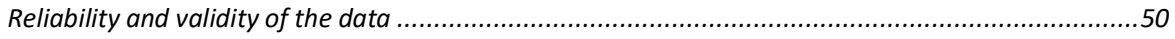

General methodological considerations ...........................................................................50

Validity of the Swedish National Patient Registry and the Cause of Death Registry ......................50

Some specific concerns about the methods .......................................................................5

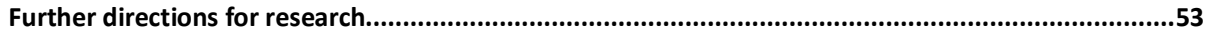

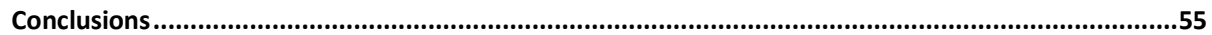

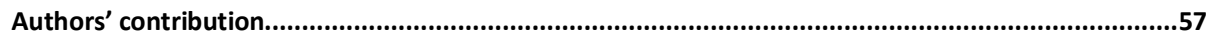

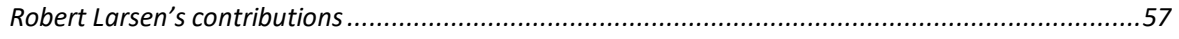

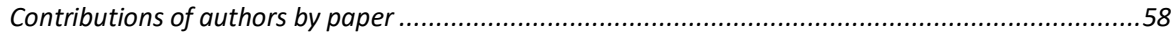

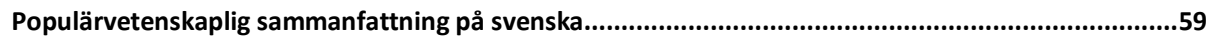

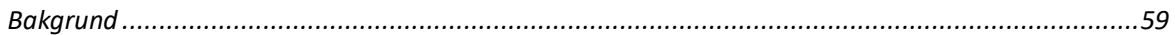

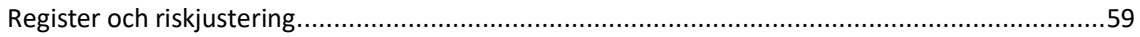

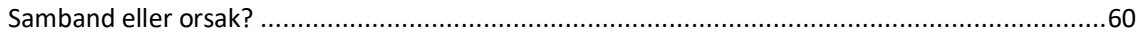

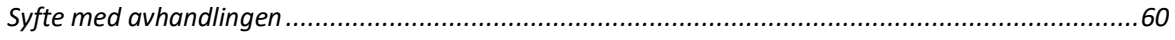

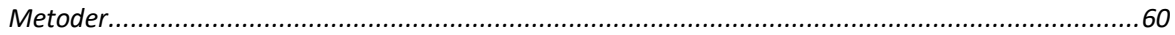

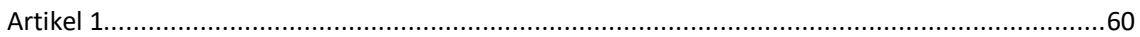

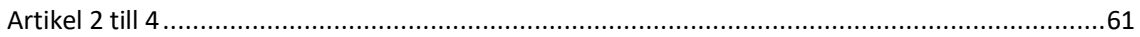

Skadejustering och andra metoder för att riskjustera .....................................................61

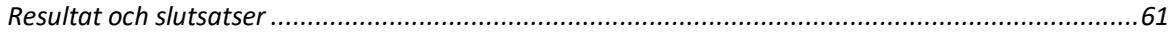

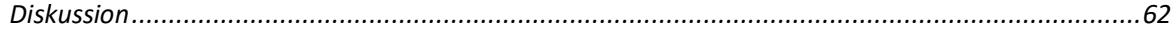

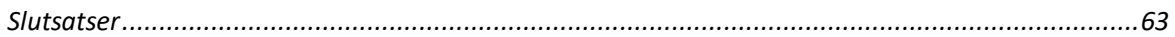

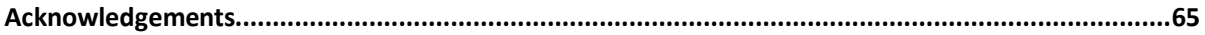

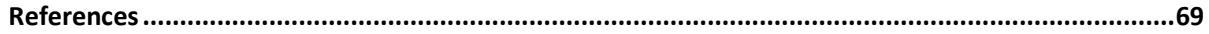

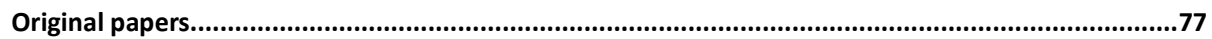




\section{ABBREVIATIONS}

$\begin{array}{ll}\text { A\&E } & \text { Accident and Emergencies } \\ \text { AIS } & \text { Abbreviated Injury Scale } \\ \text { APACHE } & \text { Acute Physiological and Chronic Health Evaluation } \\ \text { APGAR } & \text { Appearance Pulses Grimace Activity Respiration } \\ \text { AUROC } & \text { Area Under the Receiver Operating Characteristic curve } \\ \text { BC } & \text { Before Christ (e.g. time) } \\ \text { CCI } & \text { Charlson Comorbidity Index } \\ \text { CDR } & \text { Cause of Death Registry } \\ \text { CI } & \text { Confidence Interval } \\ \text { DALY } & \text { Disability-Adjusted Life Years } \\ \text { DSP } & \text { Diagnosis specific Survival Probability } \\ \text { ICD-9/10 } & \text { International Classification of Disease version } 9 / 10 \\ \text { ICISS } & \text { International Classification of disease Injury Severity Score } \\ \text { ISS } & \text { Injury Severity Score } \\ \text { NISS } & \text { New Injury Severity Score } \\ \text { NORMIT } & \text { NORwegian prediction Model In Trauma } \\ \text { NPR } & \text { National Patient Registry } \\ \text { OR } & \text { Odds Ratio } \\ \text { p } & \text { Probability-value } \\ \text { PIN } & \text { Personal Identification Number } \\ \text { r/R } & \text { Correlation Coefficient } \\ \text { r } 2 \text { R }{ }^{2} & \text { Coefficient of determination } \\ \text { RTS } & \text { Revised Trauma Score } \\ \text { SAPS } & \text { Simplified Acute Physiology Score } \\ \text { SD } & \text { Standard Deviation } \\ \text { SSR } & \text { Standard Survival Ratio } \\ \text { SweTrau } & \text { Swedish Trauma registry } \\ \text { TBSA } & \text { Total Body Surface Area } \\ \text { TRISS } & \text { TRauma Injury Severity Score } \\ \text { WHO } & \text { World Health Organisation } \\ & \end{array}$


"There is nothing like looking, if you want to find something... You certainly usually find something, if you look, but it is not always quite the something you were after."

J.R.R. Tolkien: The Hobbit 


\section{ORIGINAL PAPERS}

This thesis is based on the following papers, which are referred to by their Roman numerals (I to IV) in the text:

I. Deaths caused by injury among people of working age (18-64) are decreasing, while those among older people (64+) are increasing. Bäckström D, LARSEN ROBERT, Steinvall I, Fredrikson M, Gedeborg R, Sjoberg F. Eur J Trauma Emerg Surg. 2017; 35(4):278-596.

II. Assessment of risk-adjusted in-hospital injury mortality by ICISS model and the effect of comorbidity. LARSEN ROBERT, Steinvall I, Fredrikson $\mathrm{M}$, Walther S, Gedeborg R, Sjoberg F. In manuscript

III. Decreased risk adjusted 30-day mortality for hospital admitted injuries: a multicenter longitudinal study. LARSEN ROBERT, Bäckström D, Fredrikson M, Steinvall I, Gedeborg R, Sjoberg F. Scand J Trauma Resusc Emerg Med 2018;26(24):1-8.

IV. Female risk-adjusted advantage after injuries caused by falls, traffic or assault: a nationwide 11-year study. LARSEN ROBERT, Bäckström D, Steinvall I, Fredrikson M, Gedeborg R, Sjoberg F. Submitted and under revision 


\section{DEFINITIONS OF TRAUMA \& INJURY}

Trauma and injury are often used interchangeably, but injury tends to be the definition of choice in a wider perspective (including drowning, suffocation, intoxication and others). Trauma is often categorized within this, whereas the specific term "trauma" is saved for more severe cases. In this thesis both the terms trauma and injury are used. In an epidemiological setting it is more appropriate to refer to injury than trauma as the latter lacks a common definition.

I have defined trauma/injury as "a physiological condition driven by an anatomical abnormality", and therefore excluded all psychological trauma. In the original papers there are definitions of our study groups that all reflects this view. 


\section{INTRODUCTION}

Injuries have always been important events in human life, and therefore have often been in our minds - for example, the "big bang", which implies a lot of collateral damage, and in idioms of daily life, such as "don't let the door hit you on the way out!".

Some trauma has changed survival probability over time (hanging from an oak tree for nine night doesn't give you the ability to use runes for magic, but will probably kill you *), whereas some still remain the same (getting stabbed in the senate 23 times by your closest colleagues is still probably as lethal as in $44 \mathrm{BC}$ ).

Throughout history of mankind, there have been interesting case reports related to injuries, but regardless of how intriguing or fascinating they are, they touch upon only minor parts of the complex world of injuries.

The effect of trauma on human physiology, starts before the mechanical injury is apparent (i.e. knowing you're going to be in an incident elicits a physiological stress response), and the effects remain long after the last visit to the rehabilitation expert (i.e. being afraid of it to happen again). Injury, therefore, has long-lasting psychological, anatomical, and physiological effects for the surviving but affected humans.

However, it is often still claimed not to be adequately treated as a serious public health problem by modern society, in particular as most of the effects on those affected (such as work or socially related) remain throughout their lives, and they are often injured when they are younger than when they are affected by the other health problems that tend to occur later in life.

As an effect of this, good trauma care is still an important public health issue. Improvements in prevention and in the trauma care, which reduce the morbidity and mortality of trauma, should be prioritised within health care policies in modern societies.

* The Norse God Odin's quest for wisdom and magic

\# The murder of Julius Caesar in the senate 


\section{BACKGROUND}

Injury is a common cause of death in all ages worldwide. ${ }^{1}$ For example, in the European Union more than 40 million people are treated in hospital each year for injuries, ${ }^{2}$ and in Sweden, $7 \%$ of all deaths result from injuries. Mechanisms of blunt injury in Scandinavia are most common, and of these most happen outside hospital. ${ }^{3-6}$ One of the possible explanations is that in rural areas reporting of incident is delayed, transport times are longer and injuries are more likely to be lethal. ${ }^{7,8}$ The most serious mechanisms of injury among patients who survive long enough to get to hospital are three major groups; fall, traffic, and assault. ${ }^{9}$

\section{Sweden}

Sweden is a relatively small and safe country. In the last year of our studies (2011) the population was less than 9500000 inhabitants. ${ }^{10}$ Every resident in Sweden has a Personal Identification Number (PIN), which is organised and distributed by the Swedish Tax Agency, and links all Swedish hospital records and the Cause of Death Registry (CDR). The use of the PIN allows an almost complete coverage of every person within the Swedish healthcare system. ${ }^{11}$

To be able to examine data about the outcomes of epidemiological injuries we focused on mortality, which is usually presented as a measure of the number of deaths in a certain population, scaling it to an appropriate size (for example, /100 000 inhabitants) and sometimes examining it with a specific time as well (such as an "incident rate").

\section{Trauma registries and Risk-adjustment}

Trauma registries might be able to shed light on an area of research that is often poorly suited to a prospective, randomised, controlled clinical trial. We can learn from collecting data on the management of injuries and by comparing outcome (in this thesis, mortality) for different circumstances and by comparing them with other groups, and this comparison is often referred to as "benchmarking". When results are "benchmarked", the comparator should be aware of major biases, such as case-mix and patterns of injury, even before the most basic analysis is attempted. A comparison of crude mortality is often of limited value, because mortality varies with severity of injury. As an analogy one might argue that a comparison between apples and pears makes little sense, and a system for adjustment of risks will have to be used. Adjustment of risks is therefore a method used to adjust for differences in case-mix when outcomes are being compared amongst different groups of patients, trauma departments, hospitals, or other experimental groups.

Even after risk has been adjusted for, caution is warranted when interpretation of the results as models are based on association rather than a strict cause and effect relation. Risk-adjustment models are poor at predicting the outcome of individual patients, and are of limited interest to them, as they are constructed to examine groups of patients. Nevertheless, by the use of risk-adjusted methods, efforts to improve quality can be more accurately monitored.

Only after a valid baseline risk-adjustment has been made does an interpretation of outcomes become useful. 
A lot of different outcomes can be used but, in this thesis, I have focused on 30-day mortality. This is a well-defined outcome measure that is often used. It is comprehendible even for non-statisticians, and important for individual patients. Usually patients want to know if they are going to die of the injury, and with a cut-off period of 30 days, it might be claimed that the cause of death (if applicable) is related to the injury rather than to a new health problem, and is consistent with the Utstein recommendations. ${ }^{12-14}$

There is no perfect model available for the prediction of mortality to use after an injury. However, many different systems based on the site of injury have been examined and used for adjustment of the severity injury, and to gather large quantities of reliable data, including the ISS, NISS, and ICISS (to be described more thoroughly later).

\section{Factors that affect outcome}

Most of the injuries are not lethal in themselves but, combined with other injuries (multiple trauma) may increase the probability of dying. How lethal the trauma is may be explained by many factors, including the severity of the injury, the number of injuries, the patient's physiological reserves (a common surrogate marker is age), sex, health status before the injury (comorbidity), complications during treatment, and outcome of rehabilitation, to name but a few. 


\section{Definition of the different phases and mechanisms involved in injury and trauma}

\section{Phases of treatment}

Often when injury-related issues are being examined, the treatment is divided into different phases (such as pre-hospital, in-hospital, intra-hospital, duration of stay, and so on). During these periods the logistics and infrastructure vary locally and internationally, and unfortunately there is no common system even across Scandinavia. Possibly the biggest difference seen in the Scandinavian systems, and in comparison with Sweden, is that Sweden has few physicians (though there are some) working in the prehospital setting. This is a growing topic for discussion in Sweden and is currently (slowly) being rectified in most highly populated areas.

The Scandinavian inhospital systems, on the other hand, are more similar to each other and, in recognition of this, I am mainly restricting myself (paper II to IV) to the inhospital mortality.

Some of the important definitions used in this thesis are given below.

Prehospital is the time directly after the injury, before the patient is first admitted to hospital. This period would benefit the most from more research today as a large majority of injured patients die before they get to hospital. Over the years there has also been a growing interest in this area of treatment, and particularly the use of trained and equipped physicians during this period. It has been a topic of interest and there is growing evidence that it may alter outcome. ${ }^{15}$

Transportation times to the receiving hospital differ largely in Sweden, from minutes by ground ambulance to more than several hours by ambulance helicopters.

Hospital may be studied in subgroups. The first part of the hospital period is often spent in A\&E (Accident and Emergency department) where most often the initial hospital treatment starts. If $A \& E$ is all the patient needs, and is not admitted to hospital, that patient has not been included in the main part of this thesis or in papers II to IV. The same (exclusion) is valid for patients brought in and who died in A\&E.

If the patient needs additional treatment (admission to hospital) be it observation, surgical treatment (all types from plastic to neurosurgery), or intensive care, the patient has been included in the investigations, and considered to be a hospital inpatient.

Interhospital means that the patient needs to be transported to another hospital for a different level of care, it is considered as an interhospital period. This is different from the prehospital phase because the patient has already been assessed at a hospital, and usually initially stabilised or evaluated, there. The patient might even have been through the radiology department or had other investigations or treatments.

I do not separate the interhospital period from the inhospital period, and it is therefore included.

Rehabilitation usually starts when the patient is admitted to the hospital and extends long after final discharge. This period is encountered by most patients with trauma who survive to their arrival at the hospital and constitutes more than $97 \%$ in our hospital data. The 
later rehabilitation period is not included in this thesis, though it is an important part of the overall outcome of injury.

Measures such as DALY (Disability-Adjusted Life Years) are an important and growing research area ${ }^{16}$ and include Quality of Life after trauma ${ }^{17,18}$ but these are not covered by this thesis.

\section{Mechanisms of injury}

Our aim has been to examine different mechanisms of injury (blunt, and penetrating or high energy, or both).

The mechanisms studied in paper I to IV are shown in Table 1. Mechanism of injury varies from the most common injury mechanism in elderly patients (falling) ${ }^{19-24}$ to the more violent, assault-related injuries..$^{25,26}$

Table 1. ICD-10 codes for the different mechanisms of injury

\begin{tabular}{lcc} 
Mechanism & ICD-10 interval & Papers \\
Fall & W00-W19 & I, II, III, IV \\
Traffic & V01-V99 & I, II, III, IV \\
Assault & X85-Y09 & I, II, III, IV \\
Self-harm & X60-X84 & I \\
Poisoning & X40-X49 & I \\
Drowning & W65-W74 & I \\
Suffocation & W75-W84 & I \\
Fire, smoke or hot objects & X00-X19 & I \\
Natural/environmental & X20-X39 & I \\
Machinery & W20-W64 & I \\
Electricity, radiation & W85-W99 & I \\
Police/War & Y35-Y36 & I \\
\hline
\end{tabular}




\section{Epidemiology}

\section{Epidemiological concepts}

I would like to draw attention to some important technical issues when examining large datasets extracted from extensive registries. The statistical significance is neither necessary nor sufficient when clinical importance and relevance are being assessed.

I make no claim for the clinical relevance, as it has a lot to do with the circumstances by which it is examined. However, when discussing the statistical significance, one should be aware of the ongoing debate of lowering the p-value to 0.005 instead of the classic $0.05 .^{27}$

Probabilities of less than 0.05 were accepted as significant. In the original papers we tried to use the full value unless it was particularly small $(\mathrm{p}<0.001)$. In such cases small deviations were not judged to contribute significantly to the interpretation, as claimed by Greenland et al. ${ }^{28}$

To report the likelihood ratio, sensitivity and specificity are important, and we have used the following definitions when calculating likelihoods:

A positive result - Sensitivity/(1-Specificity)

A negative result - (1-Sensitivity)/Specificity

Sensitivity is the probability of correctly identifying the true positive cases (pointing out those who were definitely sick).

Specificity is the probability of correctly identifying the true negative cases (pointing out those who were healthy). ${ }^{29}$ 


\section{Comorbidity or cause, association or causation?}

Even if there is an association between a factor and an outcome measure, (or they coexist) it does not prove that there is a causal relation. As mentioned above, great caution is warranted when interpreting associations. A lot of factors must be considered in a conceptual way before one can claim that there is a cause-effect relation and not just an association. Factors that are biological, social, clinical, or epidemiological must be interpreted in relation to each other to be valuable for the statistical analysis. Hill presented a list of nine different aspects to consider when discussing causality in $1965 .^{30}$

1. Strength: the statistical strength of the association.

2. Consistency: the replicability of the association in question.

3. Specificity: the particularity of which one variable predicts the occurrence of another variable.

4. Temporality: the exposure must of course precede the effect.

5. Biological gradient: if there is a dose-response that can be shown, preferably with a gradient.

6. Plausibility (biological): if there is a well-established biological/pathophysiological process that can explain the association.

7. Coherence: if there is a compatibility with the existing theories or knowledge that could explain the association.

8. Experiment: if the effect be modified/scaled (even in theory) by altering the associated cause.

9. Analogy: if there is another logical basis of a known similarity, but in other aspects can derive the association.

Unfortunately, there are no tests of significance that confirm a cause-effect relation, but there is a form of strength of reasoning that will tell us if it is plausible or not.

Forty years later Lucas et al. ${ }^{31}$ published on the epidemiology of non-experimental study settings. They pointed at the quality of measurement of exposure and the previous health status as a measurement error, and of course the selection bias as well as the variability of the presentation of disease as classification bias. To strengthen their argument they also discussed maximising the signal:noise ratio, and cautioned research workers not to mistake association and causation without using Hill's criteria. They also suggested that researchers should try to limit errors, biases, and confounders before they assessed whether the associations may have had a causation.

\section{Common sources of error}

Errors may be random, systematic, or logical. Random errors are referred to as errors, whereas systematic errors are referred to as bias. Logical errors are referred to as confounders.

Error is the (unknown) difference between the retained/measured value and the true value. It has been accurately described as "an intrinsic property of a stochastic universe". 31 
Bias is a systematic error that is repeated several times. A short list of the most common biases in epidemiological studies are given below in alphabetical order.

- Detection bias: when the phenomenon you are trying to measure is more likely to be observed within a subgroup/population than the other.

- Exclusion bias: the systematic exclusion of certain individuals in the study.

- Information bias: the way data are collected and handled.

- Omission bias: during regression analysis when an independent variable that should have been in the analysis is omitted.

- Reporting bias: skewed access to data.

- Selection bias: some individuals are more likely to be selected for study than others. The contrast to exclusion bias.

Confounder is a logical error that influences or affects both the independent and the dependent variables, causing a false association.

The trustworthiness of data in especially epidemiological studies heavily rely on the level of reliability and validity. Reliability is sometimes expressed as precision or repeatability, i.e. to which extent remade measures give answers that can accurately be interpreted in the same way. In studies with high precision, the random errors are usually few. ${ }^{29}$

Validity is a measure of truth, i.e. the influence of biases. Validity can be external and more often referred to as generalizability to other populations or internal, i.e. to which extent the results are reflecting the true results within the measured population. 


\section{Rationale of research}

Injury is best described as a global pandemic. The burden is described not only in mortality but also in impairments after injury, disabilities, and loss of socioeconomic resources. That being said, injury is a true public health (and finance) problem, and from an international perspective this burden is significantly larger in low-income and middleincome countries.

Lessening the burden is often a multidisciplinary challenge with a lot of small quality steps towards a common goal that in turn demand: a pliant system that is willing to change; comparable measurable outcomes; and a broad range of resources that vary from prevention through surgical specialties all the way to rehabilitation.

Injury is a heterogeneous group that differs greatly in its global, national, and local perspectives. The risk of having an injury varies with human behaviour, socioeconomic factors, time of day, season, sex, and age.

There are differences in cause, types of injury, severity of injury, and mortality. Unfortunately, there is no good global definition of injury or trauma, or in treating, documenting, reporting, or comparing data on injured patients.

Amongst other things injury is characterized by the difficulty to make prognostic estimates as it depends on a multitude of factors including type and severity of injury, health status before the injury, resources (mental and physical), age, sex, time to treatment, and level of care and rehabilitation.

Epidemiological research as described in this thesis could be a part of the solution to the problem.

I have chosen to adopt both methods (crude and risk-adjusted) of describing a Swedish national group that has been adjusted for risk by age, sex, severity of injury (ICISS), and comorbidities. I am still aware that other confounding factors are present, but am taking a small step to understanding national trauma and the patterns in society that exist. 


\section{AIMS}

\section{General aim}

To examine injury-related mortality during the decade 2001-2011 in three major categories of injury (fall, traffic, and assault) using ICISS-based risk-adjustment data obtained from Swedish national registries (Swedish Cause of Death Registry and Swedish Inpatient Registry).

Specifically, I have examined:

- Changes in mortality over time in these different groups of injuries and the underlying type of anatomical injury.

- If the ICISS prediction model of mortality improves by adding comorbidity, as assessed by the Charlson Comorbidity Index, and obtained in parallel from the Swedish Inpatient Registry and added to information about age and sex.

- Which of the two suggested factors (hormonal or genetic) is mainly responsible for the often-observed survival advantage of women who have had major injuries. 


\section{MATERIAL AND METHODS}

\section{Patients studied}

The National Patient Registry (NPR) covers all admissions to Swedish hospitals since 1987, and the CDR covers all deaths of Swedish citizens. Records were linked using each person's unique PIN, which is given to everyone who has their permanent residence in Sweden.

\section{Paper I}

All deaths from injury in Sweden during the 14-year period, 1 January $1999-31$ December 2012, were downloaded from the CDR. Inclusion criteria were a recorded diagnoses of underlying causes of death coded by International Classification of Diseases, 10th Revision (ICD-10), diagnoses from V01 to Y36. The codings where transferred to "mechanism of injury". Admissions to hospital were gathered from the NPR.

Population data for the country were obtained from the Swedish Population Registry, and these was used for calculating mortality after injury as deaths/100,000 person-years. Incidence was calculated with age-specific groups.

\section{Paper II}

When the data were analysed, the base was analysed in two steps. One with the basic model (ICISS, age, and sex) and the other for the added Charlson Comorbidity Index score (CCI).

\section{Papers II to IV}

We used all hospital admissions for fall-related, traffic-related or assault-related injuries during the years 2001-2011 in Sweden, which we retrieved from the NPR and the CDR. These records were linked to all records in the CDR that had "injury" as the main cause of death (V01-Y98.9) using the patients' unique PIN (Figure 1). ICD-codes used are shown in Table 1.

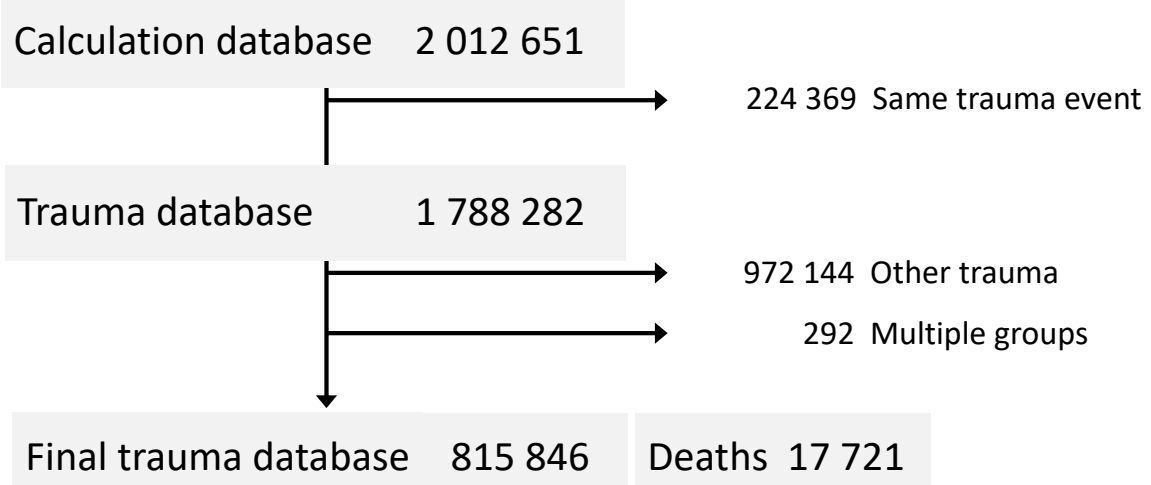

Figure 1. Flowchart showing selection of patients. 
Calculation database: data from the NPR and the CDR were combined. Trauma database: removal of duplicates (224 369) in same trauma event. Final trauma database: removal of other mechanisms than fall, traffic and assault, and of the 292 trauma recordings for patients who were classified as having more than one mechanism. The Final trauma database was used for all calculations and using the index injury as first time stamp. If there was more than 24 hours and two minutes between a hospital discharge and a new hospital admission it was treated as two separate injuries in the database. For practical reasons all the ICD codes were compiled under a single date (the index injury).

Records from which details of age, sex, date of admission, or mechanism of injury were missing were excluded from the analyses. ${ }^{32}$ The age span of the population ranged from 0 - 111 years.

\section{Mechanism of injury}

When trying to decide how to categorize the different mechanisms for paper II to IV we were baffled by the low mortality rate in our inhospital databases. Even though, our study material was based on national databases with long follow-up time we opted to just use the most lethal mechanisms for hospital mortality. In a previously published Swedish paper by Rolf Gedeborg et al. ${ }^{9}$ the mechanisms were listed. To maximize validity and reliability we chose to adopt the ICD-10 codes straight off because of the fact that all injuries have a separate code for mechanism in the ICD-10 coding system. The codes will then be used to sort the injuries into the three different mechanisms fall, traffic and assault. Table 1 shows the codes we used for coherence and repeatability.

\section{Definition of the hormonal subgroup}

In paper IV we used age categories (0-14, 15-50, and over 51 years) to compare premenarche, reproductive and post-menopausal women in Swedish women as according to Fournier et al. ${ }^{33}$

\section{Severity of injury and methods of adjusting risk}

When calculating the adjustment of risk in larger databases, age and sex are usually considered essential, and seldom tried separately. Age and sex were therefore included from the outset in all models. Risk adjustments can be physiological, anatomical, or mixed.

\section{Physiological adjustment of risk}

This type of risk-adjustment is based on physiological variables, often obtained at admission, such as the Simplified Acute Physiology Score (SAPS), ${ }^{34}$ the Acute Physiology And Chronic Health Evaluation (APACHE), ${ }^{35}$ the Appearance Pulses Grimace Activity Respiration (APGAR) ${ }^{36}$ and the Revised Trauma Score (RTS). ${ }^{37}$

The mixed risk-adjustment scales such as the Trauma Injury Severity Score (TRISS) $^{38}$ and the Norwegian prediction Model in Trauma

$(\mathrm{NORMIT})^{39}$, is a mixture of physiological and anatomical scores, and sometimes may include interventions. Mixed and physiological risk-adjustment scales will not be used or discussed further in this thesis. 


\section{Anatomical risk-adjustment}

\section{Abbreviated Injury Scale (AIS)}

The Abbreviated Injury Scale was developed by the Association for the Advancement of Automotive Medicine in the United States to classify overall severity of injury in patients with multiple injuries. ${ }^{40-42}$

The coding is done in a seven-digit format. First (1) is the body regions (head and neck, face, chest, abdomen and pelvis, extremities, external), which come from the sections: head, face, neck, thorax, abdomen and pelvis, spine, upper extremity, lower extremity and external. The second item (2) covers anatomical aspects (whole area, vessels, nerves, organs, skeletal, loss of consciousness), and then specific anatomical structures $(3,4)$ (such as skin abrasion, laceration, amputation, level of consciousness, cervical, lumbar, and so on) followed by the specific injuries $(5,6)$, which are assigned a two-digit number. Last (7) the injuries are then assigned an internal score on a six-grade scale from minor to un-survivable (1 to 6) and a separate "not further specified" score, a score of nine (9).

The limitations of the AIS (valid for both Injury Severity Score(ISS) and New Injury Severity Score (NISS)) are: first, the arbitrary system of rating and the internal validation and interrater reliability. ${ }^{42}$ There has been a suggestion that AIS should not be used as a basis for severity in trauma, ${ }^{40}$ but it is widely used, and considered by many to be a gold standard.

\section{Injury Severity Score (ISS)}

In the anatomical risk-adjustment scales, ISS is the gold standard, ${ }^{43}$ but there are important issues with it that must be highlighted.

One important limitation is the fixed number of injuries included (three) and the need of a specially trained person to assign the scores. Another serious shortcoming is the arbitrary nature and internal validation of the scoring system. Last, and not least, un-survivable injuries are excluded (rated a score of 75) and hence become a selffulfilling prophecy.

To get a proper ISS value you need to find the three worst injuries (according to the scorer) in separate and different body regions. The seventh (7) AIS severity value for each of the regions is then squared and the values summed for the ISS value (for example: $2^{2}+4^{2}+1^{2}=21$ ). The ISS-value can vary from 1 to 75 .

If there is an injury classified as unsurvivable (6) the calculations are stopped and the ISS value is set to a fixed $75 .{ }^{43}$

As in most anatomical classification systems the scoring is done after the initial phase, so you are able to correct your numbers. The treating clinician then has to learn that a score of more than 15 (even if Palmer et al. think that a score of 12 is severe ${ }^{44}$ ) is regarded as severe, and a score of 75 is either dead or as close as possible to dead.

Internal validation is a problem when assigning the "worst" injuries, as there are clinicians treating the patient who do not code the ISS-score. ${ }^{42}$ Another problem is that when squaring and adding numbers you lose the obvious gradient in the scale. 


\section{New Injury Severity Score (NISS)}

The limitation of different body regions is corrected in the NISS, ${ }^{45}$ which is the same scoring of ISS accept it includes the three worst injuries regardless of body region. The problem with internal validation and interrater variability is the same with NISS as in ISS.

\section{International Classification of disease Injury Severity Score (ICISS)}

In 1996 Osler et al. ${ }^{46}$ developed a new scoring system based on the hospital discharge diagnoses (International Classification of Disease 9:th edition (ICD-9)) to try to remedy some of the uncertainties of the anatomical risk-adjustment scales of the ISS. He named it International Classification of disease Injury Severity Score (ICISS). It has since been showed to outperform ISS in mortality prediction even so when converted to ICD-10 (10:th edition of ICD codings) and to be a valuable tool when applied to bigger databases as the codes are taken from the hospital administrative databases recorded for both economical and administrative purposes. ${ }^{46,48}$ The easy access to big material in Sweden makes ICISS an ideal research tool as well as for follow-ups both in-hospital/country and comparison between hospitals. ${ }^{47}$ Since you can easily calculate an ICISS value on a cohort the update frequency is less important than in the case of AIS.

ICISS has been used and evaluated several times at the international level, European level and in a nationally in Sweden. ${ }^{47-53}$ A recent meta-analysis has also supported its use to assess trauma mortality. ${ }^{48}$

The way to calculate ICISS is by either using someone's Diagnosis-Specific Survival Probabilities (DSP) or to calculate your own database. The mathematics are simple; the proportion of patients who survive a specific injury (Standard Survival Rate - SSR) is the DSP. You could either calculate it as "exclusive" or "inclusive". The exclusive way is when the patient had only one injury, and theirs is the SSR for that in a population. The inclusive way is more common, and it takes into account all the injuries that the patient had, and calculates the SSR of that - for example, of all patients with femoral fractures (anywhere in the diagnosis list) what proportion survived?

I have chosen to use the inclusive way. The DSP will vary between 0 (no survivors) and 1 (no fatalities) with each DSP. Having criticised ISS for being too narrow in the number of diagnoses, Osler ${ }^{46}$ showed that the first six diagnoses strengthen the model, and adding more did not appear to harm it. We opted for up to 10 diagnoses (one main diagnosis and up to nine secondary ones), as did Osler. ${ }^{46}$

The ICISS for individual cases was calculated as the product of DSP corresponding to the patient's injury codes (that is, the product of each probability for survival after the injury) up to the nine secondary diagnoses.

$I C I S S=D S P_{\text {main diagnosis }} \times D S P_{\text {secondary diagnosis } 1} \times D S P_{\text {secondary diagnosis } 2} \times D_{S P}$ secondary diagnosis...(etc. to 9 th $)$ 
This is an example, with made up injuries. A poor patient has been stabbed and burned: traumatic shock gives a DSP of 0.590 , multiple injuries of vessels in the abdomen give a DSP of 0.706 , burns of $72 \%$ of the total body surface area (TBSA) have a DSP of 0.455 , and finally, the inhalation injury has a DSP of 0.677 . This fictitious patient had an ICISS (a survival chance) of $0.128(13 \%$ survival chance $)(0.59 \times 0.706 \times 0.455 \times 0.677=0.128)$ from the injuries listed. Table 2 lists our true DSP on the 20 diagnoses that were most closely associated with in hospital mortality according to the ICISS analysis in this thesis.

Table 2. Twenty lowest DSP in the datasets.

\begin{tabular}{|c|c|c|c|c|}
\hline $\begin{array}{l}\text { ICD- } \\
10\end{array}$ & Authors plain explanation & DSP & $\begin{array}{l}\text { No of } \\
\text { injuries }\end{array}$ & $\begin{array}{c}\text { No of } \\
\text { survivor } \\
\text { s }\end{array}$ \\
\hline T054 & $\begin{array}{l}\text { Traumatic amputation, one foot and the other } \\
\text { leg }\end{array}$ & 0 & 1 & 0 \\
\hline $\mathrm{T} 353$ & Freezing injuries of torso & 0 & 2 & 0 \\
\hline T318 & Burns $80-89 \%$ TBSA & 0.452 & 31 & 14 \\
\hline T317 & Burns $70-79 \%$ TBSA & 0.455 & 33 & 15 \\
\hline S480 & Traumatic amputation at the shoulder & 0.471 & 17 & 8 \\
\hline T056 & $\begin{array}{l}\text { Traumatic amputation upper and lower } \\
\text { extremities, regardless of combination }\end{array}$ & 0.500 & 2 & 1 \\
\hline T063 & $\begin{array}{l}\text { Injuries to blood vessels that supply several } \\
\text { regions of the body }\end{array}$ & 0.500 & 2 & 1 \\
\hline T267 & $\begin{array}{l}\text { Chemical burns that result in rupture and } \\
\text { destruction of an eyeball }\end{array}$ & 0.500 & 2 & 1 \\
\hline T326 & Chemical burns $60-69 \%$ TBSA & 0.500 & 2 & 1 \\
\hline T327 & Chemical burns $70-79 \%$ TBSA & 0.500 & 2 & 1 \\
\hline T319 & Burns $90 \%$ or more TBSA & 0.514 & 35 & 18 \\
\hline T791 & Fat emboli & 0.545 & 55 & 30 \\
\hline T347 & $\begin{array}{l}\text { Freezing injury, necrosis of the lower } \\
\text { extremity }\end{array}$ & 0.588 & 17 & 10 \\
\hline T794 & Traumatic chock & 0.590 & 229 & 135 \\
\hline $\mathrm{T} 719$ & Suffocation & 0.648 & 438 & 284 \\
\hline T324 & Chemical burns $40-49 \%$ TBSA & 0.667 & 6 & 4 \\
\hline T373 & $\begin{array}{l}\text { Intoxication with drugs against Protozoa } \\
\text { (Arsenic?) }\end{array}$ & 0.667 & 3 & 2 \\
\hline $\mathrm{T} 272$ & Inhalation injury & 0.677 & 31 & 21 \\
\hline S159 & Injury to non-specified vessel in the neck & 0.700 & 50 & 35 \\
\hline S357 & $\begin{array}{l}\text { Multiple injuries to the vessels in the } \\
\text { abdomen and pelvis }\end{array}$ & 0.706 & 68 & 48 \\
\hline
\end{tabular}

It should be noted that environmental factors such as thermal and chemical burns, freezing, and inhalation injuries make up half the list.

There is no consensus about how low an ICISS must be to be considered severe. However, a $15 \%$ mortality rating (i.e. ICISS 0.85 ) has previously been considered severe. ${ }^{54}$

A limitation with ICISS is that uncommon diagnoses might get DSP that are not expected (by a clinician). As a fictional example: a patient is intoxicated with organophosphate (the nerve-gas sarin). He struggles for 29 days on the brink of death in the ICU the whole time, but walks out alive on day 30 . As the patient is the only one in 
the database with this specific intoxication, the DSP is 1 . If the same patient died at day 31 , the DSP would still be 1 (because he survived 30 days from the index time), although if he died on day 30 , the DSP would be 0 .

In papers II to IV injury severity was defined by the ICISS. We used the index injury (the first admission date) and then collected all the ICD codes for the following care regardless of whether the patient was moved or not.

\section{Comorbidity (coexisting conditions)}

Comorbidity is a surrogate marker for how healthy you were when the injury happened. This is also an estimate of the physiological reserves as well as age at the time of injury.

In papers II to IV the Charlson Comorbidity Index score (CCI) was calculated using the weighted scale as described in the original paper ${ }^{55}$ and the ICD codes from Christensen et al. ${ }^{56}$ One could argue that the CCI is old and not adapted to trauma care, but it is a well-known comprehensive scale with high epidemiological impact, so we opted to use it.

\section{Mortality}

In paper I, prehospital death was defined as death with no recorded hospital admission, and death in hospital was defined as death with a date of admission. We chose the mortality/100 000 person years to evaluate prehospital mortality, and included only the primary diagnosis as the cause of death so that the late deaths not primarily caused by injury were excluded.

In paper II to IV, mortality was calculated based on the date of death being within 30 days of the index injury date (30-day mortality).

Data from the CDR were available until 31 December 2012, which allowed at least 12 months' follow-up after the date of admission to hospital (considered to be the index date of the injury) and the date of death was retrieved and paired with the latest injury.

In paper III we used a more specific 30-day mortality/100 000 inhabitants for international comparison.

\section{Age}

Age is a good pseudomarker for physiological reserves, and one of its better known uses is the Baux score for mortality after burn-related injuries. ${ }^{57}$ Together with the size of the burn, this explains $97 \%$ of the outcome. ${ }^{58}$ If one could make an argument against the Baux score, it would be that it's linearity may not be transferable to all sorts of trauma.

\section{Sex}

Female sex has been shown in models (mainly animal but also human) to be associated with improved survival. Table 7 shows the survival benefit for female patients in our database. However, the debate is ongoing about whether the protective model of female sex is the result of genetics or hormonal protection. ${ }^{59-63}$ Paper IV evaluates the effect of sex on 30-day mortality. 


\section{Year}

Time is always an interesting factor in clinical studies. Paper III investigates this further in our model. 


\section{Statistical analyses}

Incidence/100 000 person years was calculated using national data retrieved from the Statistics Sweden open database for population. ${ }^{10}$ We chose the denominator of 100000 , as death is a rare event in our series.

Table 3 shows the statistical methods used in each paper. The models are further explained below.

Table 3. Statistical tests used in the papers

\begin{tabular}{|c|c|c|c|c|}
\hline \multirow[t]{2}{*}{ Method } & \multicolumn{4}{|c|}{ Paper } \\
\hline & $\mathbf{I}$ & II & III & $\mathbf{I V}$ \\
\hline Brier score & & $\mathrm{X}$ & & \\
\hline Scaled Brier score & & $\mathrm{x}$ & & \\
\hline Cox's calibration & & $\mathrm{x}$ & & \\
\hline Hosmer Lemeshow's goodness of fit & & $\mathrm{x}$ & & \\
\hline $\mathrm{r}^{2}$ & $\mathrm{X}$ & & & \\
\hline pseudo- $\mathrm{R}^{2}$ & & $\mathrm{x}$ & & $\mathrm{X}$ \\
\hline Chi squared test & $\mathrm{X}$ & $(\mathrm{x})$ & & \\
\hline Wilcoxon (Mann-Whitney $U$ ) test & & $\mathrm{X}$ & & \\
\hline Student's $t$ test & $\mathrm{X}$ & & & \\
\hline Kruskal Wallis & & $\mathrm{x}$ & & \\
\hline AUROC & & $\mathrm{X}$ & $\mathrm{X}$ & $\mathrm{x}$ \\
\hline Linear regression & $\mathrm{X}$ & & $\mathrm{X}$ & \\
\hline Logistic regression & & $\mathrm{x}$ & $\mathrm{x}$ & $\mathrm{X}$ \\
\hline Wilk's theorem & & $\mathrm{x}$ & & \\
\hline
\end{tabular}

The parenthesis states that it is used indirect

\section{The Brier score and scaled Brier score}

The Brier score is used as a global measure that evaluates the risk estimation values. In paper II it is used as an overall measurement of accuracy. Even though it was first used in meteorology ${ }^{64}$ to evaluate the accuracy of weather forecasts it can be used in epidemiology for a similar purpose. A Brier score has a perfect value of 0 and a noninformative model has the value of 0.25 , because it is the difference between observed and predicted (mortality) that is squared for each patient.

When trying to normalise the Brier score (into a scaled Brier score) the scaled score can assume scores of $0 \%$ to $100 \%$ ( 0 to 1$)$ where $100 \%$ is the perfect value. This makes it easier to compare different mortality rates among different models. ${ }^{65}$

\section{Cox's calibration and Hosmer Lemeshow's goodness of fit}

Cox's calibration is often confused with Cox's semiparametric test, but it is not the same. Cox's calibration regression is a regression analysis with dead/alive as the outcome. The intersection (Cox's intercept) is where this linear equation crosses the y-axis and the slope (Cox's slope) is the tilt of the line. For perfect fit the intercept should be 0 and the slope 1.66

A more traditional way of testing calibration is by using the HosmerLemeshow goodness of fit either in C-statistics or H-statistics. C-statistics divide the material into equal parts and plot the predictive/actual-risk, whereas $\mathrm{H}$-statistics divide the risk into equal parts and plot the predictive and actual risks (an example is shown in Figure 2 without a significant change in $\mathrm{C}$-statistics but with a significant change in $\mathrm{H}$ statistics). A printout of the data is required to assess the plots. 

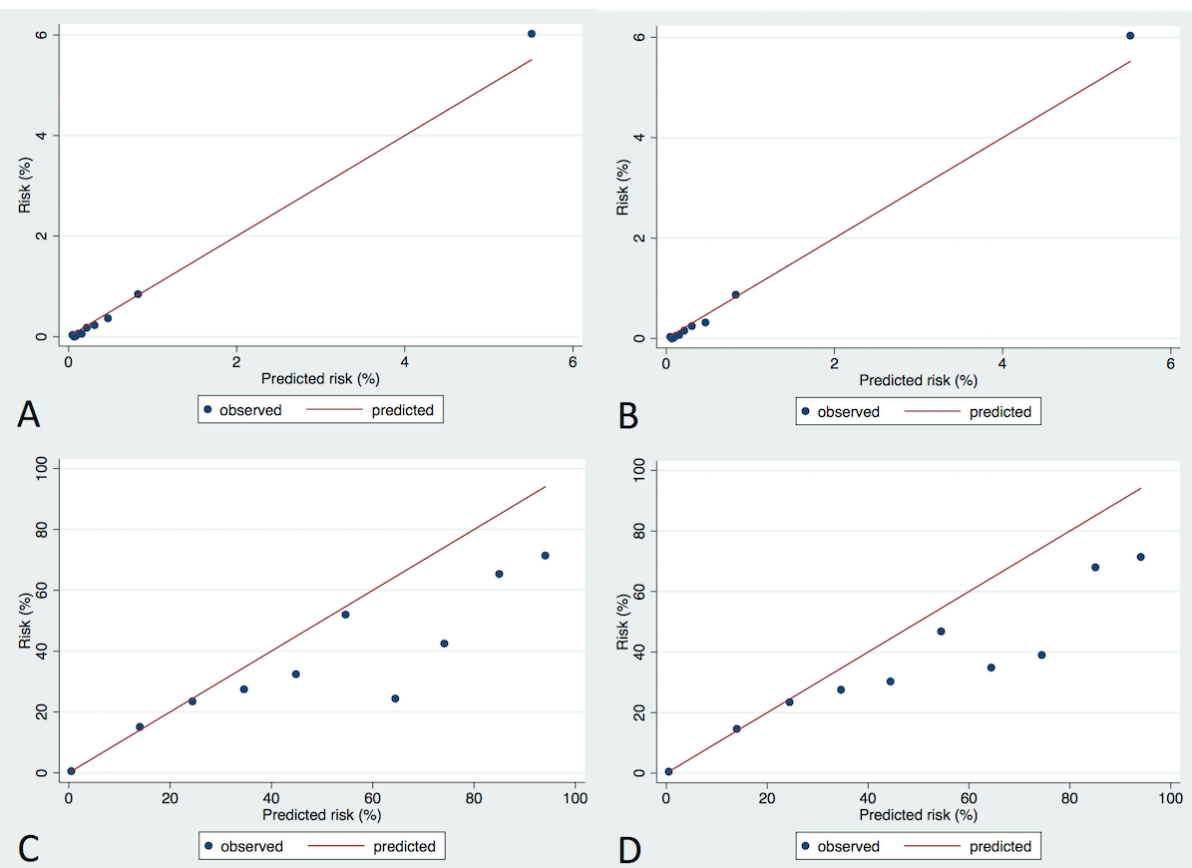

Figure 2. C- and $\mathrm{H}$-statistics for the basic model of traffic-related injuries $(\mathrm{A}+\mathrm{C})$ and with the Charlson Comorbidity Index score (B + D).

Kramer et al showed that in larger databases the goodness of fit will be significant (that is, a bad calibration) because of the large size of the database, ${ }^{67}$ but with the use of Hosmer-Lemeshow chi squared values the models can be compared in a standardised way. I have used the Hosmer-Lemeshow test in a comparative way only in this study by increasing the dataset one degree of freedom to compare the fit. ${ }^{68,69}$

\section{Coefficient of correlation and coefficient of determination}

The correlation coefficient is a statistical measure of the relation between two variables, ranging from -1 (inversely perfect) to 1 (perfect) ${ }^{70}$ In this thesis the coefficient of correlation is indicated by $\boldsymbol{r}$ in linear regressions and $\boldsymbol{R}$ in logistic regressions.

When $\boldsymbol{r}$ is squared it becomes the coefficient of determination $\left(\boldsymbol{r}^{2}\right)$, and explains the amount of variation in a linear regression model. When the same manoeuvre is being used for logistic regression the value is called pseudo- $\boldsymbol{R}^{2}$ (pseudo coefficient of determination) and, even though it is harder to interpret and there is an ongoing debate if it should be used at all, it is still used as a measure of statistical strength in the same way as $\boldsymbol{r}^{2}$.

\section{Comparison of different subgroups}

A chi squared is used to calculate whether the significant of the difference between the observed and expected values. It would, however, be more correct to use it by its full name: Pearson's chi squared test.

Wilcoxon test (the Mann-Whitney $U$ test) is a non-parametric test used to identify differences between two groups. Being non-parametric it does not rely on normal distribution of the variable of the groups being tested, unlike the Student's $t$ test. 
The Student's $t$ test is like the Wilcoxon test with the exception that a normal distribution of the variable is required for it to function optimally.

A Kruskal Wallis test is also a non-parametric test, and is used to compare two or more independent samples (not necessarily of the same sample size). It can be said to extend the Wilcoxon test beyond a two-group comparison and was used as a follow up to a Wilcoxon test in paper II for pairwise comparison of the groups.

\section{Discrimination}

Discrimination is used to distinguish the survivors from the non-survivors, but can be used for comparison of any two mutually exclusive groups. In this thesis it is measuring 30-day mortality. The most common measure of the model's performance is the concordance (c), which is often referred to as c-statistics and is the same as the area under the receiver operating characteristic curve (AUROC).

When constructing a receiver operating characteristic (ROC) curve the sensitivity (true positive rate) plots against 1-specificity (false positive rate) for all observed values. The AUROC can have a value that is between 0.5 to 1 , where 1 is a perfect discrimination for survival, and 0.5 cannot discriminate between survivors and those who died.

Roughly, an AUROC of $>0.7$ is good, $>0.8$ is very good, and to reach $>0.9$ is usually regarded as excellent, although there is no common definition and values over 0.95 are rare. Figure 3 is an example of a ROC curve.

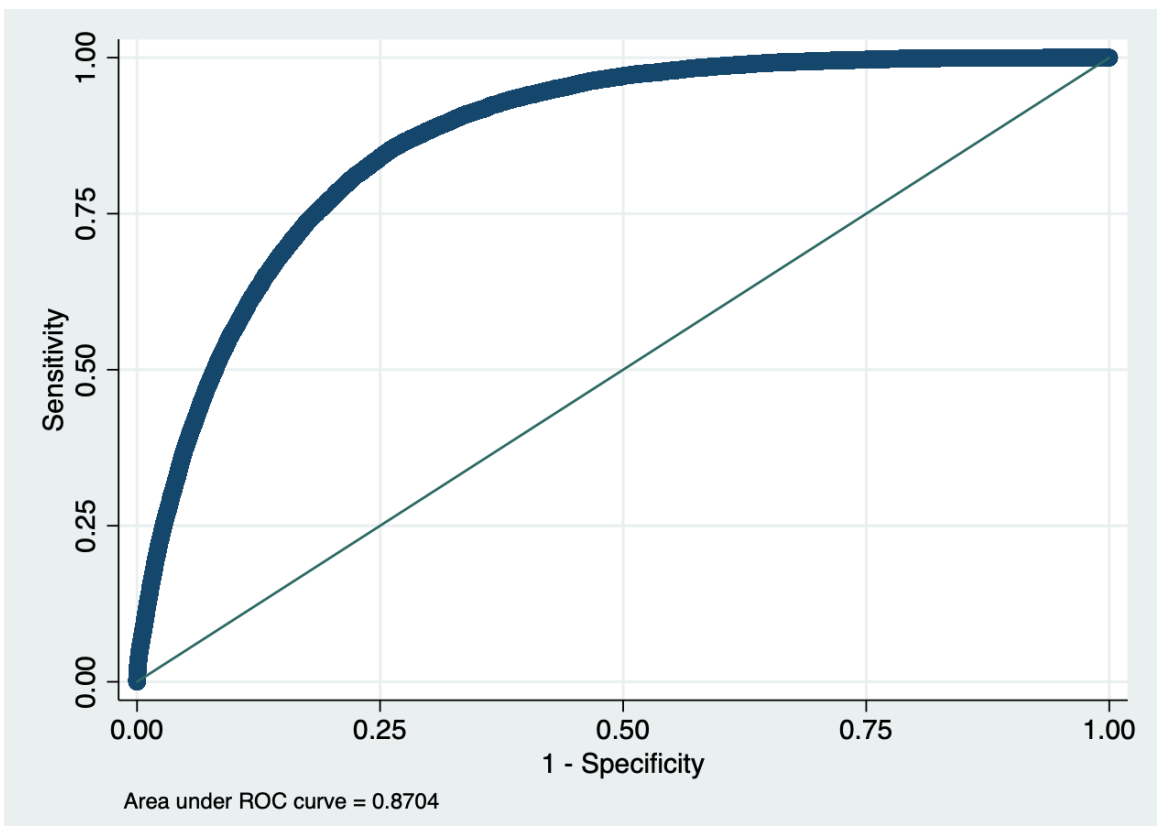

Figure 3. Example of a ROC curve 


\section{Associations}

Linear regression must be thought of as the basic skill in modelling the relation between a dependent variable and one or more independent variables. It is easy to understand and to interpret. In the papers in this thesis it is used to estimate trends in incidence of injuries over time in paper III and for all the regression analyses in paper $\mathbf{I}$.

The logistic model (sometimes referred to as logit model) is a statistical model for the probability that the binary dependent variable is a function of the independent variables, which might not be binary (that is, the model itself simply models probability of output in terms of input).

In papers II to IV logistic regression models were used to estimate the associations. All the models used logistic regression for 30-day mortality. Numerical variables were used in the models as linear effects without transformation.

Because ICISS may not have a linear relation with the logit of mortality, ICISS were modelled both as linear effects and as a restricted cubic spline in the logistic regression models. There was no difference on the seventh decimal (data not shown), so the linear relation with logit was used in the papers in this thesis.

\section{Likelihood}

Likelihood is the probability of the occurrence of a specified event if the material is independent and is normally distributed - that is, generalisability. If the series is big and there are several probabilities of things that might occur, the logarithmic likelihood modifies densities into a sum. A sum could easily be handled by computers (probably the main reason for log likelihood as a value).

Log likelihoods are compared with each other by Wilk's theorem, which states that:

"Under regularity and under $\mathrm{H}_{0}$, the limiting distribution of $-2 \ln \lambda$ is chi-squared, with degrees of freedom equal to the number of restrictions imposed. $" 68$

In short, if you increase the degree of freedom by 1 and the log likelihood differed by more than 3.84 the significance would be $\mathrm{p}<0.05$. 


\section{Statistical software and significance}

For paper I, we used Statistica version 12 (Dell Inc, Tulsa, OK, USA) to analyse data. Data for papers II, III and IV were managed and analysed by Stata (Stata Corp LP 201117, Stata version 12-15, College Station, TX, USA).

Probabilities of less than 0.05 were accepted as "statistically" significant, but I must emphasise that statistical significance is neither necessary nor sufficient for assessing clinical importance. 


\section{Ethics approval}

All studies conducted in this thesis were approved by the Regional Ethics Review Board in Linköping, Sweden

Ethics approval: within M21-09 with amendments and supplemental files. 


\section{Investigational variables}

Paper I used mortality as dependent variable and did separate calculations for each mechanism. In paper II to IV we have chosen to use 30-day mortality as the dependent variable and injury severity, age, sex and comorbidities as independent variables. In paper III we also used year as an independent variable (Table 4).

Table 4. Variables used in papers I to IV

\begin{tabular}{cccccc}
\hline Variable & Independent & Min & Median/Mean & Max & $\begin{array}{c}\text { Used in } \\
\text { papers }\end{array}$ \\
\hline 30-day mortality & & 0 & $0.000 / 0.022$ & 1 & II, III, IV \\
ICISS & $\mathrm{x}$ & 0.089 & $0.951 / 0.932$ & 1 & II, III, IV \\
Age & $\mathrm{x}$ & 0 & $66 / 58$ & 111 & II, III, IV \\
Sex & $\mathrm{x}$ & 0 & $2.000 / 1.542$ & 1 & II, III, IV \\
CCI & $\mathrm{x}$ & 0 & $0.000 / 0.189$ & 9 & II, III, IV \\
Year & $\mathrm{x}$ & 2001 & 2006 & 2011 & III \\
Mortality & & 1 & 1 & 1 & I \\
Year & $\mathrm{x}$ & 1999 & 2006 & 2012 & I \\
\hline
\end{tabular}




\section{RESULTS}

In paper I the expected value of two-thirds of the patients as male ${ }^{19}$ did appear, but to our surprise it did not carry over to the hospital records, as $45 \%$ of the injured patients were male in our database for papers II to IV (Table 5). Although, we usually refer to a trauma series as comprising two-thirds male patients, we could not find this in our unadjusted inhospital database. When we adjusted for the severity of the injury and used "severe trauma" 54 as the inclusion criterion we still found that only $57 \%$ patients were male. As can be seen in Table 5, the two-thirds cut-off (of male patients) occurred at an estimated mortality of $25 \%$ (ICISS 0.75 ), including a mere $13 \%$ of our data. Table 5 shows the number of remaining patients by sex as ICISS decreases.

Table 5. ICISS and part male patients. 30-day mortality rates for

\begin{tabular}{ccccc}
\multicolumn{2}{c}{ men and women. } & \multicolumn{3}{c}{$\mathrm{n}$; 30-day mortality } \\
$\begin{array}{c}\text { ICISS } \\
\text { under the } \\
\text { value of }\end{array}$ & $\begin{array}{c}\text { Male \% of } \\
\text { patients }\end{array}$ & $\mathrm{n}$ & Male & Female \\
1.00 & 45,8 & 815846 & 8679 & 9042 \\
0.99 & 45,3 & 769085 & 8585 & 8975 \\
0.95 & 41,4 & 399917 & 8103 & 8406 \\
0.90 & 40,4 & 231361 & 7185 & 7123 \\
0.85 & 57,5 & 49631 & 2250 & 1620 \\
0.80 & 61,8 & 19836 & 1204 & 705 \\
0.75 & 66,5 & 10870 & 935 & 495 \\
0.70 & 67,9 & 6586 & 735 & 360 \\
0.65 & 68,7 & 3644 & 482 & 235 \\
0.60 & 70,0 & 2113 & 341 & 154 \\
0.55 & 70,0 & 1170 & 218 & 105 \\
0.50 & 70,0 & 606 & 135 & 70 \\
\hline
\end{tabular}

From an epidemiological standpoint our data failed to show that patients with injury are usually male, as the largest group of hospital inpatients is in fact female. 
Most of our patients did not have any comorbidities (see Table 6 for CCI, Table 7 for mean CCI and Figure 4 for mean CCI by cause of injury). This is further investigated in paper II.

Table 6. Number of patients by CCI score

\begin{tabular}{ccccc}
$\begin{array}{c}\text { CCI } \\
\text { score }\end{array}$ & \multicolumn{4}{c}{ Number of patients by category } \\
& Total & Fall & Traffic & Assault \\
\hline 0 & 715507 & 542663 & 146633 & 26211 \\
1 & 72120 & 66346 & 5027 & 747 \\
2 & 19054 & 17464 & 1510 & 80 \\
3 & 5539 & 5233 & 296 & 10 \\
4 & 29 & 24 & 5 & 0 \\
5 & 10 & 10 & 0 & 0 \\
6 & 841 & 752 & 76 & 13 \\
7 & 183 & 174 & 9 & 0 \\
8 & 2114 & 1976 & 135 & 3 \\
9 & 449 & 432 & 17 & 0 \\
\hline
\end{tabular}

Table 7. Mean CCI by age group

\begin{tabular}{ccccc|} 
Age group & \multicolumn{4}{c|}{ Mean CCI } \\
& Total & Fall & Traffic & Assault \\
\hline $0-14$ & 0.0087 & 0.0081 & 0.0100 & 0.0159 \\
$15-25$ & 0.0142 & 0.0157 & 0.0128 & 0.0152 \\
$26-35$ & 0.0215 & 0.0264 & 0.0184 & 0.0164 \\
$36-45$ & 0.0409 & 0.0477 & 0.0321 & 0.0398 \\
$46-55$ & 0.0945 & 0.1066 & 0.0720 & 0.0723 \\
$56-65$ & 0.1927 & 0.2049 & 0.1477 & 0.1279 \\
$66-75$ & 0.3215 & 0.3318 & 0.2434 & 0.1651 \\
76 and over & 0.3069 & 0.3075 & 0.2926 & 0.2174 \\
\hline
\end{tabular}

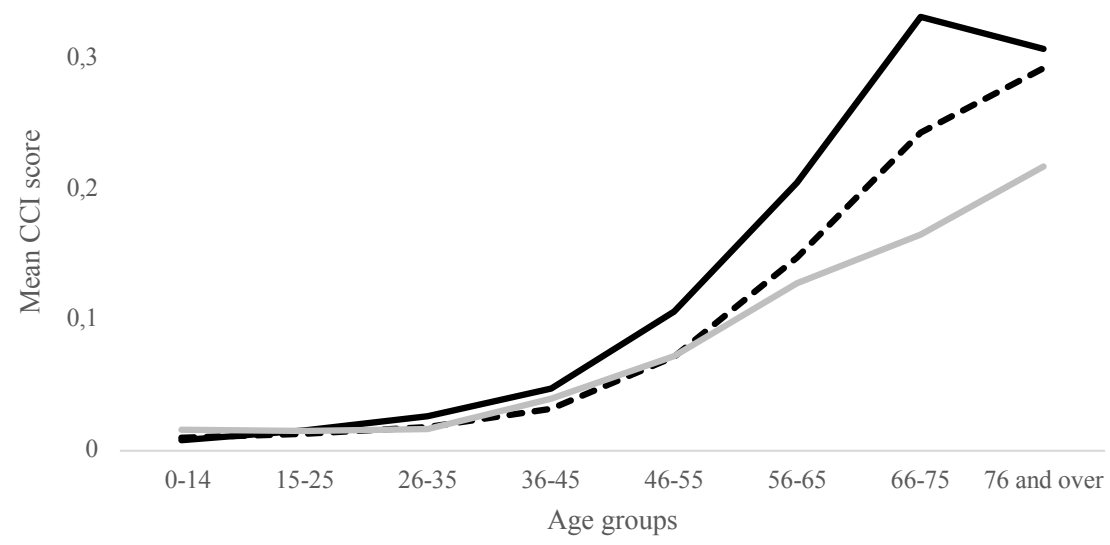

Figure 4. Mean Charlson Comorbidity Index (CCI) score by cause of injury. Solid black line $=$ injuries caused by fall, dotted black line $=$ injuries caused by traffic and solid grey line $=$ injuries caused by assault. 
When adding the CCI score, the accuracy, calibration, and discrimination increased significantly according to Wilk's theorem (Table 8).

Table 8. Pseudo R ${ }^{2}$, AUROC and log. Likelihood for the coefficient of determination and discrimination

\begin{tabular}{llll} 
All & Pseudo $\mathrm{R}^{2}$ & AUROC & log. likelihood \\
ICISS & 0.0971 & 0.8105 & -77097.86 \\
ICISS age & 0.1966 & 0.8638 & -68599.51 \\
ICISS age sex & 0.2081 & 0.8704 & -67621.27 \\
ICISS age sex CCI & 0.2150 & 0.8759 & -67033.11 \\
\hline
\end{tabular}

The difference between models is considered significant when the log. likelihood values differ greater than 3.84 (as adding one degree of freedom).

Figure 5 shows the Hosmer-Lemeshow plots of the overall groups. As anticipated the effect was biggest in the risk-adjusted fall-related injury group which had the highest mean CCI score (see Table 6).
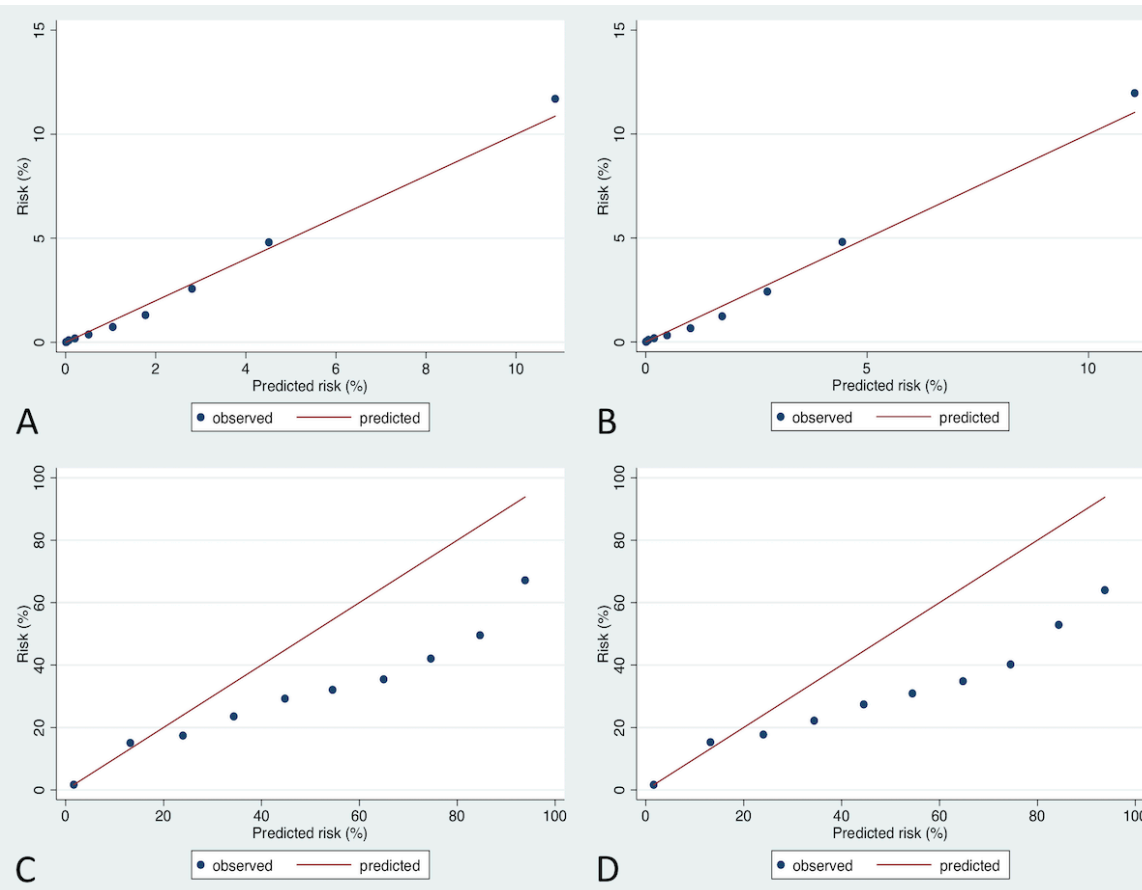

Figure 5. $\mathrm{C}$ and $\mathrm{H}$ statistics for the overall basic model $(\mathrm{A}+\mathrm{C})$ and with Charlson Comorbidity Index score $(\mathrm{B}+\mathrm{D})$.

Paper III shows a decrease in risk-adjusted 30-day mortality during the study period. This has probable to do with changes in medical treatment (pre- or in-hospital) to the better.

In Paper I, the overall crude mortality did not change from 1999 to $2012(32 / 100000$ person-years to $33 / 100000$ person-years). The incidence of fall-related injuries increased with a coefficient of $0.34(\mathrm{p}<0.001)$. Traffic- and assault- related injury decreased in the same period $(-0.27, \mathrm{p}<0.001$ and $-0.03, \mathrm{p}=0.006$, respectively) 
When we tried to replicate the crude results in the hospital group, the incidence of fall and traffic-related injuries decreased over time (2001-2011), fall-related from 689 to $636 / 100000$ inhabitants, a coefficient of $-4.71, p=0.047$, and traffic-related from 169 to $123 / 100000$ inhabitants, a coefficient of $-5.37, \mathrm{p}<0.001$.

We could not find a decrease in the in-hospital group for assault-related injuries during the same period of time.

After risk-adjustment, there was an overall decrease in 30-day (OR 1.0; CI95\% 0.99 to $1.00, \mathrm{p}=0.008$ ) This is probably because of the large number of patients within the database.

The decrease in traffic-related and assault-related risk-adjusted 30-day mortality was significant (traffic-related OR 0.95; 95\%CI 0.93 to $0.97, \mathrm{p}<0.001$ and assault- related OR 0.93 ; $95 \%$ CI 0.87 to $0.99, \mathrm{p}=0.022$ ) whereas falls did not change during this 11 -year period.

Given that the assault-related injuries decreased by approximately $7 \% /$ year during our study period, there was a total decrease of 55\% for risk-adjusted, 30-day mortality during our study period. Traffic-related injuries decreased by $5 \%$ /year, which adds up to a $43 \%$ decrease in risk-adjusted 30-day mortality over the period. The cumulative effect was bigger than anticipated.

When mortality is compared with increasing age there is an exponential increase (Figure 6). Age is one of the factors that changes the pseudo $\mathrm{R}^{2}$ the most. Table 8 and Table 9 show the characteristics in our model according to age groups by mechanism of injury.

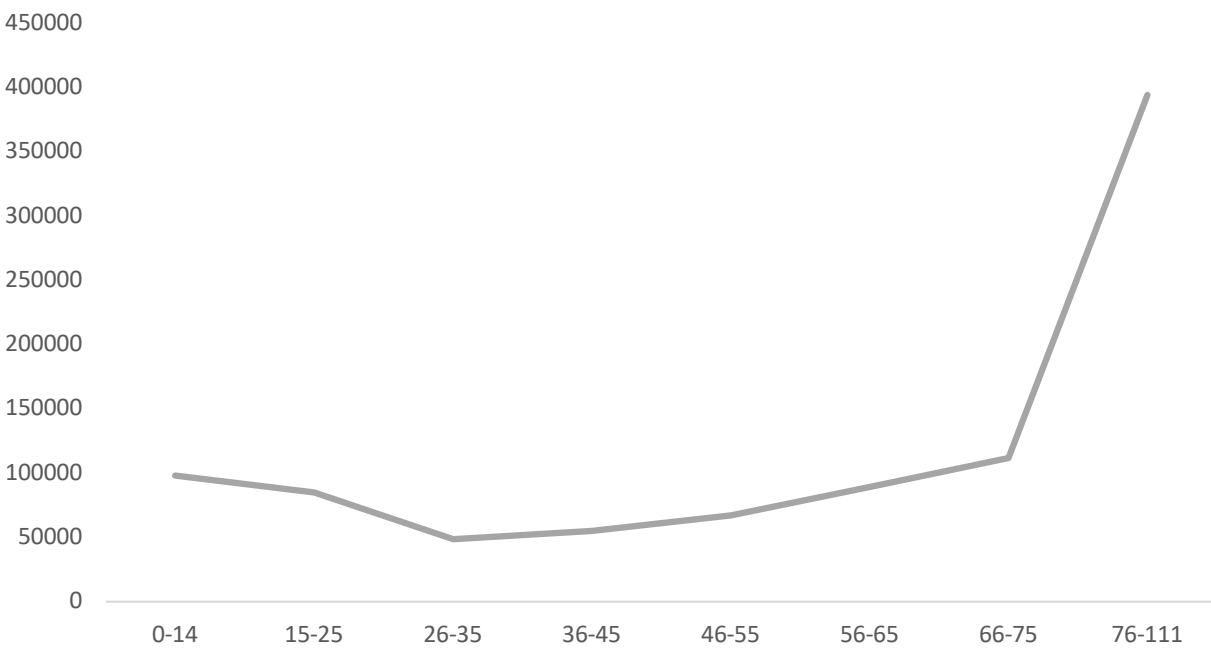

Figure 6. Thirty-day mortality by age group within the injuries caused by fall-related, traffic-related, and assault-related injuries. 
Table 9. Characteristics of patients by cause of injury

\begin{tabular}{lllll}
\hline & All & Fall & Traffic & Assault \\
Patients & 815846 & 635074 & 153708 & 27064 \\
Male & 373811 & 259759 & 93186 & 20866 \\
Mean (SD) age in years & $58(29)$ & $64(27)$ & $37(22)$ & $33(15)$ \\
Age & & & & \\
$0-14$ & 95135 & 70162 & 23966 & 1007 \\
$15-25$ & 76252 & 27513 & 38259 & 10480 \\
$26-35$ & 42924 & 17937 & 19627 & 5360 \\
$36-45$ & 48978 & 25356 & 19197 & 4425 \\
$46-55$ & 59355 & 38657 & 17295 & 3403 \\
$56-65$ & 77769 & 61672 & 14557 & 1540 \\
$66-75$ & 93029 & 82697 & 9805 & 527 \\
76 and over & 322404 & 311080 & 11002 & 322 \\
\hline
\end{tabular}

In paper I we could measure a notable decline in mortality for male patients of workingage (coefficient $-0.54, \mathrm{p}=0.015$ ) while no such effect could be found among women. Risk adjusted analysis showed that the decrease in 30-day mortality for the entire group was evident (coefficient $-0.014, \mathrm{p}<0.001$ ) and when we separated the groups we could still find an effect for men but not a significant one for women (coefficient $-0.023, p<0.001$ and $-0.006, p=0.091$ ).

A female survival benefit was present in all subgroups, which could be explained by the survival benefit being oestrogen dependent, but when we had adjusted for injury severity, age, and comorbidity we could find no support for a hormonal effect to explain it.

To our surprise the protective effect increased with age. Figure 7 is a graphical representation of the CI by hormonal group. It should be noted that the mortality in the pre-menarche group is small in both sexes, resulting in greater uncertainty.

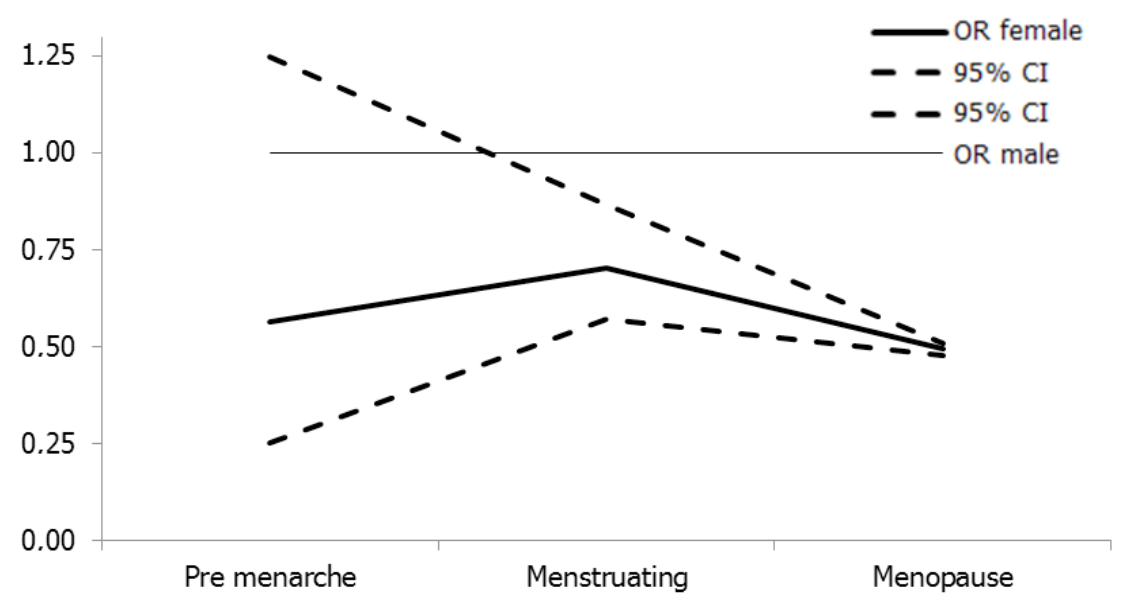

Figure 7. Risk adjusted odds ratio for 30-day mortality after injury by hormonal groups (the male is reference). Thick black line $=$ Female OR, dashed black lines shows $95 \% \mathrm{CI}$.

When we tried the theory with age groups as in paper III, it only decreased the precision and widening the CI but with an unchanged result (data not shown). 
Further investigation of the difference between the sexes, showed that there was also a difference in comorbidity. Table 10 shows that the mean CCI differs between the sexes in the inhospital group, with a non-overlapping CI. However, it is noticeable that it is well below 0.2 CCI-score - in other words, a relatively healthy population.

Table 10. Mean CCI by sex

Sex $\quad$ Mean CCI $\quad 95 \%$ CI

Male $\quad 0.196 \quad 0.194$ to 0.198

Female $\quad 0.183 \quad 0.181$ to 0.185




\section{DISCUSSION}

In this thesis I have tried to examine injury from the incident until discharge from hospital or death, so that I cover most of the events related to the early progress after injury. This encompasses most of the treatments given, but does not include the rehabilitation phase where we know that considerable progress is made.

This does not mean that the long-term results after trauma are less important. On the contrary, knowing the final outcome is important for the priorities of care instituted, and underlines the well-known potential effects of rehabilitation. This has also been described in a number of papers that have investigated the long term outcome after trauma, such as the ones based on measures of health-related quality of life. ${ }^{17,18}$

One main finding in the first paper of this thesis was the magnitude of prehospital mortality. This has been shown repeatedly in Scandinavia, and suggests that high priority should be directed to prevention and prehospital care by Gedeborg et al. ${ }^{9}$

Another important finding was that there was a decline in mortality after injuries over time in people of working age. Interestingly this effect was most pronounced for men, which is something that has been shown for other types of trauma, such as burns. ${ }^{71}$ This suggests that men's behaviour, which is described as more prone to risk than that of women, is being controlled in modern societies.

The large number of prehospital deaths in people of working age is most certainly caused by the overall number of self-inflicted injuries. Suicides are by definition designed to be lethal, and that may be a significant factor in the large prehospital death rates. ${ }^{7,72}$ Overall the number of prehospital deaths has in Scandinavia been reported to be between $45 \%$ and $85 \%{ }^{3-5,7-9,22,72-74}$ The present data that indicate the large number at working age $(87.5 \%)$ is to our knowledge the highest yet reported in Scandinavia. However, there is an age selection bias because the overall prehospital mortality was $72 \%$ in our study.

I think that part of the high mortality prehospital might also be because there is no organised national system that includes physicians who specialise in prehospital care in Sweden.

Some studies have suggested that including prehospital care physicians in the early accident rescue team would have an important impact on immediate mortality after trauma. ${ }^{75}$ This, however, may be a subject for discussion or accentuation, because of the variations in demography - for example, in The Netherlands or Germany the distances between hospitals are short, in contrast to Sweden.

The next three papers in the thesis focus on risk adjustment of injuries, as some aspects will not be depicted by crude mortality - for example, improvements in care - which is important to investigate if the aim is to decrease morbidity and mortality for any given type of injury.

Many applications have been developed in the field of risk adjustment in the health care sector, most of which are within critical care, such as the APACHE ${ }^{35}$ and SAPS $^{34}$ systems, or for paediatric ICU care the Paediatric Index of Mortality (PIM). ${ }^{76}$ However, other areas are important as well, such as the diagnosis of cancer, which has scales that measure the spread of the tumour by the TMN-system ${ }^{77}$ or in neonatology, the APGAR Score. ${ }^{36}$ The most used and evaluated system in injury and trauma is the ISS, which is based on the AIS. ${ }^{40-42}$ 
However, it is demanding on the health care system to record these injury scoring systems as part of everyday clinical care, as specially educated staff are needed, and a separate organisation needs to be built and maintained. ${ }^{40-42,46,47}$ Given these shortcomings, the best use of them is in the US, and in areas with a special interest in injury or in dedicated trauma centres.

Having these shortcomings in mind Osler et al launched the ICISS in 1996. This system has several advantages in that it uses ICD-coding, which has usually already been implemented and is in place in most health care systems. This has happened in Sweden, where ISS is not yet well used, but several research groups have successfully added the ICISS to the Swedish tradition of registries. The latter has provided the backbone on to which the ICISS risk adjustment system may be used.

With this in mind the last three papers were designed.

Firstly, the ideas about methods used in paper II developed. In his original publication, Osler did not adjust for age, sex, and comorbidity, and it was soon recognised that these three factors would affect the ICISS mortality prediction model. This is mentioned in the papers by Bergeron ${ }^{78}$, Stephenson ${ }^{79}$ and Davie. ${ }^{80}$ However, the repeated addition of age and sex was primarily the work of Gedeborg, $, 91,82$ and it was soon appreciated that age had a significant effect on the prediction of mortality. He also applied the ICISS mainly to the cause of death registry, which encompassed all prehospital mortality, ${ }^{9}$ which strengthened the prediction of mortality by ICISS considerably.

In the subsequent papers in this thesis (II to IV) the low mortality in the inpatient registry, together with the large number of patients with injuries who were at low risk of death, reduces the strength of the model. In paper II the effect of comorbidity together with age and sex was examined and, contrary to the pre-study hypothesis, the effect of comorbidity was limited, particularly compared to that of age. This was so even in the subgroup with comorbidities, but we were surprised to find how low the overall incidence of comorbidity was in the group with injuries who were admitted to hospital. This can certainly be explained by the lower overall age of the group, which is lower than that seen in patients in ICU. ${ }^{17,18}$

Secondly, in paper II, the addition of comorbidity (as Charlson Comorbidity Index score) significantly improved the overall accuracy of prediction of mortality from injury, together with discrimination and calibration, despite the fact that age and sex were included in the model. Comparing the model's predicted outcomes (accuracy, calibration, and discrimination) in the present study with previously published data, the specifics for accuracy, calibration, and discrimination are similar. ${ }^{32,48,81}$

When comparing our data with the 90-days mortality perspective of Mitchell $^{83}$ and Davie ${ }^{80}$ the data were still comparable, with a few exceptions. Compared to Davie ${ }^{80}$ we used age and sex a-priori to the discrimination analyses and in comparison to Mitchell ${ }^{83}$ we used age as a continuous variable not a categorical. These finding supports the validity of the model and the consistency of the underlying data in the database. 
Thirdly, in paper II we used the ICISS to examine injury from the perspective of the three major subgroups of injury falls, traffic, and assault. These three subgroups had previously been used in models based on ICISS, mainly by Gedeborg, and it has some advantages in that it separates injury into three groups that have different backgrounds. The fall-related group is older and has more comorbidities than the other two, there is higher energy trauma in traffic-, and there are more penetrating injuries in the younger assault-related group.

This also affected the mortality prediction model, in that the more homogeneous groups - traffic- and assault-related - showed a better model compared with the fall-related group. The fall-related group, encompassing the factors mentioned above as well as other possible factors that might increase the risk of death.

In paper III risk-adjusted mortality was examined from the time perspective and with a focus on possible effects of improvements in care in injuries made over a decade. When we studied the effect of time on outcome, we found a decrease in risk-adjusted 30-day mortality for traffic-related and assault-related injuries, but a non-significant small decrease in 30-day mortality for fall-related injuries even though the crude numbers decreased during the 11-year study period. When we evaluated the yearly reduction of $7 \%$ compared with 5\% (assault-related compared with traffic-related injuries) it added up to an impressive cumulative decrease of $55 \%$ compared with $43 \%$ over the study period.

It should be noted that an important shortcoming in the assault-related group is the total numbers of patients in conjunction with fewer fatalities, both of which reduce the power of the trauma model. The improved outcome in the traffic-related group was astonishingly good and may be the result of factors other than improvements in health care. I must emphasise that traffic-related mortality has decreased by almost $50 \%$ overall in recent years, and it could be argued that not only the mortality but also the magnitude of each injury is less. However, the adjustment of the data is based on specific injuries, so it could be argued that we are really comparing the same injuries but with a more recent, better outcome.

Further issues of importance in this paper depend on the two different groups that are classified as fall- and assault-related. The former is a group with injuries that range from high energy, high altitude, injures in construction work in the working age with few if any comorbidities, to falls in the home in elderly people with considerable comorbidities. This makes the group heterogeneous, and this is seen in the lower prediction values in fall- as compared to traffic-related, for example.

I think that the smaller decrease in risk-adjusted (age, sex, comorbidity, and year), fallrelated, 30-day mortality could also be part of a systemic bias, whereas traffic-related and assault-related injuries are high-profile under all circumstances. As high-profile causes, implementation in change of care is easier and more research goes into these areas.

However, there is a public healthcare problem with fall-related injuries, as they are not currently enjoying the same benefits of the current, high-energy, trauma systems, and that needs to be addressed and corrected in the future (both clinically, in trauma-courses and as far as the study of trauma is concerned). 
Another challenge was the inability to quantify the energy in fall-related injuries with the correct ICD-codings. The heterogenous nature of the ICD-codings is illustrated by "falling from one level to another" which, when evaluated a bit further, could span both "falling down a flight of stairs" and "falling out of a plane", which makes it difficult to calculate a dose:response relation.

These 13208 patients in the group "falling from one level to another" were comparable according to 30-day mortality, sex, and comorbidity with the rest of fallrelated injuries with the exception that almost $5 \%$ were infants (less than a year old). Fallrelated injuries still remain one of the most interesting parts of this thesis, as it is hard to find comparable international data.

The reduction in crude numbers are probably attributable to preventive measures, and several projects have been started in Sweden during the last 20 years to help with both work-place-related injuries and injuries in geriatric care facilities. ${ }^{84}$ The time between admission and operation in geriatric patients who had fallen has been thoroughly debated in the medical community. ${ }^{85}$

We evaluated the effect of age to find out if it is linear or exponential, and even though it is a clear exponential curve it did not affect the prediction significantly when squared (data not shown). We chose to keep it as a solitary variable in the logistic regressions while being aware of its behaviour.

The topic for the last paper (paper IV) was the recurring and clear finding of a survival benefit for female sex that we saw in the repeated analyses. This topic has been wellstudied and is a "hot" one. From the experimental perspective it is well documented in animal studies that female sex has a survival benefit in trauma and sepsis, and the reason for this has been repeatedly addressed. ${ }^{86-89}$

Two theories have been prevalent, the effect of the female sex hormone oestrogen, or the mosaic X chromosome theory. ${ }^{59-63}$ However, clinically data have not been as convincing, as outcome advantages have been shown for both male and female trauma. For example, in burns both male and female survival advantages have been claimed based on registry studies. ${ }^{89-91}$ In cardiac care women have been found to obtain poorer care with worse outcomes as a result. ${ }^{92}$ It is interesting that female patients get less nursing time in the ICU without any survival disadvantage. ${ }^{88,93}$

Although risk-adjustment and level of care go beyond this study, it is easy to see that further studies could and probably should be made. 


\section{Strengths:}

A strength in this thesis is that that the data were collected from national registries that apply to every Swedish inhabitant, which gives us a relatively "statistically noise-free" registry that has been shown to be of good quality. ${ }^{94}$ Health care in Sweden is publicly financed, so it is not dependant on the patient's economic welfare or insurance. I think, therefore, that the model shows physiological rather than confounding effects.

This comprehensive database is based on the exact person-based linkage of hospital discharge records with cause of death and accurate estimates of the severity of injury. The underlying coding of injuries in the Swedish NPR has previously been validated to the fourth position of the code..$^{95}$

The relatively long study periods of this thesis (11 or 14 years) is a valid strength, as it minimises the risk of drawing incorrect conclusions based on unrepresentative years. For comorbidity the follow-up time was even longer, with the first recorded in 1987 and the last on 31 December 2012.

We have investigated both crude prehospital, and crude inhospital, mortality to evaluate both before dealing with risk-adjusted mortality.

ICISS provides an accurate estimation of the severity of injury. ${ }^{50}$ Sweden has been shown to compare well with other industrialised countries internationally. ${ }^{81}$ When we added CCI to ICISS, age, and sex, the discrimination of the model increased. We have tried to evaluate the 30-day mortality model thoroughly beyond the ordinary scope of discrimination and a calibration plot.

\section{Limitations:}

Limitations of the thesis are that it is retrospective and covers a small, rich and safe country, although, in the other Scandinavian countries the picture is roughly the same. ${ }^{81}$ Some types of injuries are rare even in a nationwide study, which adds an element of uncertainty to the estimates for calculating ICISS, particularly in the subgroup of assaultrelated injuries.

The quality of registry data should normally be regarded with a degree of caution. However, Ludvigsson et al. ${ }^{94}$ have shown that the National Swedish Registries are of high quality. Despite this, the injured group has only about a $10 \%$ prevalence of comorbidities, which in contrast to other studies might be low. That could affect the small effect of adjusting for comorbidities.

Fall-related injuries is a heterogeneous group as far as age, sex, and comorbidities are concerned, and the severity of injury within the same ICD codes (falling from different levels does not give an indication of the impact on the body - for example, falling from a chair and falling from a flight of stairs) could be a factor leading to slightly less discrimination in the fall-related group.

Assault-related injuries are few in crude numbers but have a lower than expected mortality, which unfortunately leads to less precision.

I could not find a good way to make a biological gradient in any of the mechanisms, as was tried in the Hill criteria (as seen below). 
Another limitation is the expected misclassification of hormonal levels, such as from postmenopausal hormonal replacement. This could be further examined in Sweden today by using the Medical Prescription Registry.

Finally, one could imagine that patients readmitted and deceased after our 30-day limit would change the dataset, but when we calculated 90-day mortality (data not shown) the differences were small.

\section{Generalisability:}

This thesis will be of most interest to those interested in epidemiology, as it illustrates the possibilities of risk-adjustment before and after interventions for trauma, or how to compare outcome in different departments or hospitals. ${ }^{96}$

Most mortality happens before admission to hospital, and most patients who survive to hospital will survive; this pattern is similar to that described from other highincome countries. This has been covered from the strict perspective of generalisability by Gedeborg who pooled data from different parts of the world and examined them using ICISS. ${ }^{81}$

\section{Testing causality using Hill's criteria}

As mentioned earlier, Hill in 1965presented a list of nine aspects that should be considered when causality is discussed ${ }^{30}$ The methods used in paper $\mathbf{I}$ are different from those used papers II to IV. Paper I will be tested separately.

\section{Paper I}

The statistical strength in paper I is expressed as the square of the correlation coefficient (coefficient of determination) where the ranges from 0 to 0.88 must be considered as extremely poor to excellent. It is therefore hard to evaluate the statistical strength of paper I as one paper. However, the $\mathrm{r}^{2}$ values are high in some analyses. The consistency is clearly stated in conjunction with that of other Scandinavian countries. ${ }^{3-5,7,9}$ Temporality is clear because the injury is before the effect (death). Plausability and coherence are clear. However, the biological gradient is harder to calculate because of the lack of internal ranking within the injuries. The experimental part is a point for discussion: can the effect (death) be altered if the cause (injury) is changed or modified? Although we have no evidence of this, we are certain of it. Lastly, the analogy - we can find no better logical explanation.

\section{Papers II to IV}

We will use the results from paper II when discussing the statistical strength, as it was constructed to evaluate the model. The statistical strength of the associations in the complete model is very good to excellent as far as the AUROC of the results in paper II are concerned, and ranges from 0.875 to 0.924 (total and traffic-related). With an excellent Brier score, scaled Brier score, and Cox calibration we can certainly say that the statistical strength is good. The consistency is equally easy to rank as high, because results are roughly the same worldwide with the newest article by Mitchell et al as a good example. ${ }^{83}$ The specificity is harder to see, but if one reason's that age precedes comorbidity, then both age and comorbidity have an effect on mortality. However, we have not investigated whether the specific 30-day mortality and comorbidity are better 
than any other mortality interval, and the interaction between the two must be more thoroughly examined to be able to make more than educated guesses. The temporality is obvious, because the injuries precede the mortality. As with paper I the biological gradient is hard to calculate. We tried to grade fall-related injuries, but unfortunately it could not be done adequately by using the ICD system. The plausibility and coherence are clear from those involved in injury research. Discussion of the experimental criteria is much the same discussion as that for paper $\mathbf{I}$, but as far as we know no more evidence has emerged. As for analogy, we still find this the most logical explanation but we might be missing something obvious.

Table 11. Summary of Hill's criteria, papers I to IV

\begin{tabular}{lccc} 
Criteria & Fulfilled & $\begin{array}{c}\text { To some extent } \\
\text { fulfilled }\end{array}$ & $\begin{array}{c}\text { Not } \\
\text { fulfilled }\end{array}$ \\
$\begin{array}{l}\text { Statistical strength } \\
\text { Consistency }\end{array}$ & $\mathrm{x}$ & & \\
$\begin{array}{l}\text { Specificity } \\
\text { Temporality }\end{array}$ & $\mathrm{x}$ & $\mathrm{x}$ & \\
$\begin{array}{l}\text { Biological gradient } \\
\text { Plausibility }\end{array}$ & $\mathrm{x}$ & & \\
$\begin{array}{l}\text { Coherence } \\
\text { Experiment }\end{array}$ & $\mathrm{x}$ & & $\mathrm{x}$ \\
Analogy & & $\mathrm{x}$ & \\
\hline
\end{tabular}

\section{Causality}

As can be seen in Table 11, even though all the papers fulfil the criteria to different extents, it is obvious when we summarise them in a table that we cannot give a definitive answer about causality.

However, to summarise paper $\mathbf{I}$, it is probable that the associations shown reflect causation, but they probably do not explain the whole effect.

To summarise papers II - IV, it is probable that the associations are the result of causation. However, that is not the complete story because there is still part of the 30-day mortality after injuries related to falls, traffic, and assaults that is not explained by the current model. 


\section{Reliability and validity of the data}

\section{General methodological considerations}

As far as the reliability of the data are concerned, they were all collected from the national registries with good coverage and good internal validity. ${ }^{11,94}$ However, the accuracy of ICD coding may be debated. "Lost" ICD codes at discharge have been mentioned in other studies, ${ }^{94,95}$ and the ICD coding may be influenced (as mentioned earlier) by non-medical or economic factors in that some codes are paid more than others. This is called the "diagnostic drift". ${ }^{97}$

The inclusion of either the CDR or NPR was done by the administrative staff of the Swedish Board of Health and Welfare (experienced professionals at Socialstyrelsen), who even did the second matching between the registries when needed. These procedures minimised the risk of random errors and increased the reliability and precision of the thesis. To maximise the internal validity, the first author used the same statistician for all work on the databases and advanced analyses. Data for external validity were collected from national data and, to our knowledge, no centres were missed. This should present reasonably generalisable results within the scope of each paper.

\section{Paper I}

The external validity of paper I cannot be generalised for the entire range of trauma or population. It is however, an excellent paper for injuries of patients aged 18 years and older, with a single worst injury.

\section{Papers II to IV}

In papers II to IV the patients were analysed by groups, adjustments having been made for injury, age, comorbidity, and - in some cases - sex and year. The papers all used large databases, which minimised the risk and effect of random errors and, as a consequence, provided good reliability. It should, however, be noted that despite the large databases some diagnoses were rare and overall mortality was low.

\section{Validity of the Swedish National Patient Registry and the Cause of Death Registry}

The Swedish NPR has a close to $100 \%$ coverage for inpatient care, as has the CDR. Compared with chart reviews the coding in the NPR has a high specificity of $85 \%-95 \%$, but a lower sensitivity (as low as $8 \%$ for hypertension). ${ }^{94}$ The problem is similar for the $\mathrm{CDR}$, and this effect may be anticipated to get larger with time as the Swedish necropsy rate has been declining, to as low as $11 \%$ in $2013 .{ }^{98}$ 


\section{Some specific concerns about the methods}

Even when doing registry research for an entire nation some of the diagnoses will appear infrequently. That will lead to bigger methodological errors (confounders). For example, if you have a serious, and most times deadly, injury that the patient survived, it would be a false (compared to reality) high DSP, and vice versa.

However, pooled DSP have been shown not to add enough information to be worth collecting when constructing ICISS. ${ }^{81}$ One should bear in mind that even though there is a high probability for causation, all papers are modelled associations. The change in method should not be a confounder if one notes that in paper $\mathbf{I}$ the worst injury is the inclusion criterion, whereas in papers II to IV the models are constructed with a multitrauma perspective. We cannot see that the change of setting is such a large confounder that the studies are not comparable. 


\section{FURTHER DIRECTIONS FOR RESEARCH}

Fall-related injuries are by far the largest group, and although we tried we could not find a good way to make a biological gradient in the group.

Fall-related injuries alone warrant a thesis.

Traffic-related injuries are probably the one group we had the most external questions about, and the interest to keep on evaluating them is great, and we think that it is comparable for most of the industrialised world.

However, we would like to combine our system with that used by the road transport agency (Statens Väg- och TransportforskningsInstitut-VTI) for recording the speed limit at the place where the injuries happened. We think that this is a factor that would add to our model. Another thing that would be interesting to evaluate is whether the position in the car (driver or passenger) would contribute to our model.

In papers II to IV I could find no evidence for the "tri-/bi-" modal mortality described earlier, and used in traumatology. When looking for the "second bump" in mortality in hospital there were no evidence of it ever happening. Figure 9 shows a plot of 30-day time-to-death by percentage in our series.

The different modes previously discussed in trauma mortality (trimodal or bimodal mortality profiles), therefore, are now best described as the "ski slope" modality.

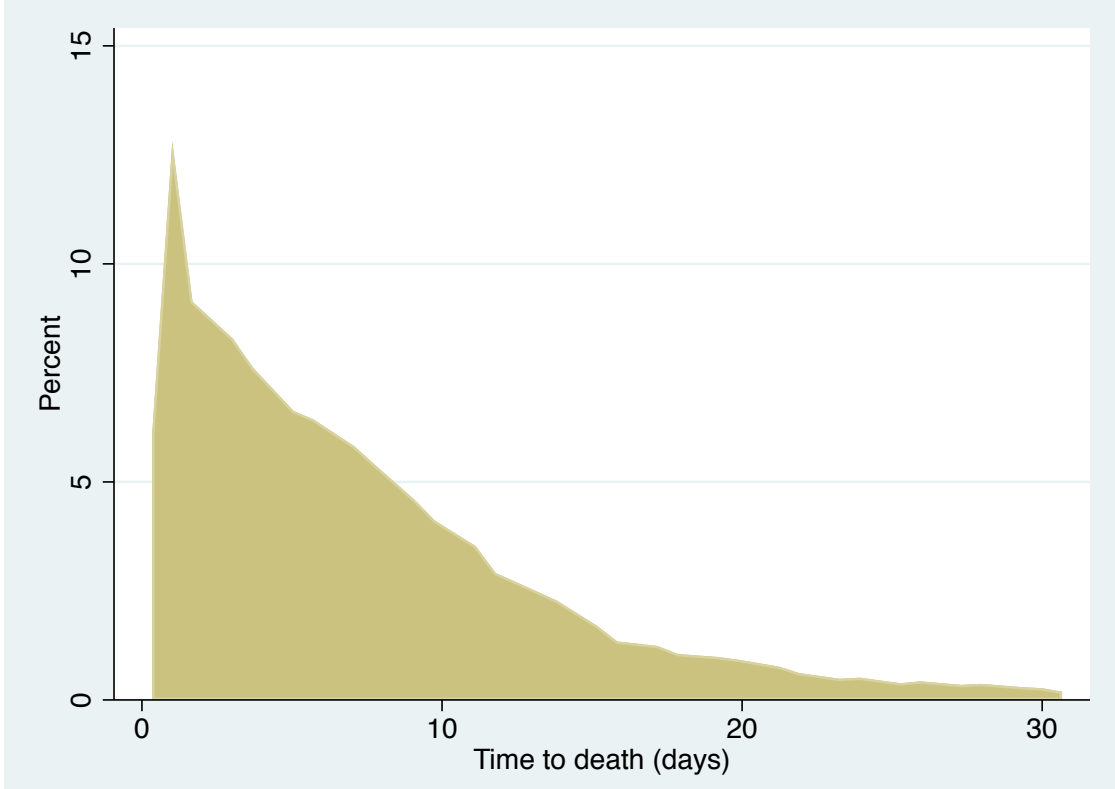

Figure 9. Time to death (days) $(\%)$ in the series. 
The addition of the prehospital to the hospital section when calculating ICISS should improve the predictive probability and using those DSP tests on a separate group within Scandinavia would be useful.

It would be interesting to continuing the idea of Bergeron et al. ${ }^{78}$ idea and benchmark the different hospitals in a nationwide study within the same level of care (trauma centre, non-trauma centre), and by comparing different levels of trauma care with each other, particularly as Celso et al. in $2006^{99}$ estimated the survival benefit in trauma centres at a staggering $15 \%$.

The ICISS should be combined with physiological variables to evaluate if it is possible to improve the predictive power even more, and it should be compared with other mortality variables currently in use locally, such as the Estimated Mortality Ratio in the Swedish Intensive Care Registry and maybe the Swedish Trauma Registry (SweTrau).

Ulvik et $\mathrm{al}^{93}$ published an important paper, however, they used ISS and SAPS II and categorised age. Knowing what we know of ISS, it would be beneficial to repeat this with the same ICISS model as the rest of the series. 


\section{CONCLUSIONS}

When investigating injuries, the crude and risk-adjusted information is as different in many aspects as is the prehospital and inhospital data. To get a wider perspective of the epidemiology of injury we need to evaluate both crude and risk-adjusted mortality as well as looking at the bigger picture, with prehospital deaths included as well as specific groups for those patients in hospital.

I recommend using both crude and risk-adjusted data, and the use of the Swedish national registries NPR/CDR creates clear trends in the incidence of injuries, and can be used for good risk-adjustment.

Using ICISS for adjusting for injury severity is simple and did well in prediction models for 30-day mortality in the group in hospital during the years 2001-2011. Adding comorbidity to the model of ICISS, age, and sex improved the ability to predict the 30 day mortality by getting a better accuracy, calibration and discrimination in the inhospital group.

When we investigated the female survival benefit in the risk-adjusted (ICISS, age, sex, and comorbidity) group in hospital we were unable to find supportive evidence for the theory that oestrogen has a protective effect. Instead, we found an increasing survival benefit with increasing age. 


\section{AUTHORS' CONTRIBUTION}

\section{Robert Larsen's contributions}

Contributions by Robert Larsen to each paper included in this thesis (Table 12).

Table 12. Authors contribution by paper

\begin{tabular}{lcccc} 
Robert Larsen's responsibility & \multicolumn{4}{c}{ Paper } \\
& I & II & III & IV \\
Conception and/or design & - & a & a & a \\
Planning of the study & - & a & a & a \\
Acquisition of data & - & a & a & a \\
Analysis and interpretation & b & a & a & a \\
Drafting the paper & c & a & a & a \\
Journal correspondence & b & a & a & a \\
\hline a. main responsibility & & & & \\
b. contributed to high extent & & & & \\
c. contributed & & & &
\end{tabular}




\section{Contributions of authors by paper}

RL - ROBERT LARSEN, DB - Denise Bäckström, IS - Ingrid Steinvall, MF - Mats Fredrikson, SW - Sten Walther, RG - Rolf Gedeborg, FS - Folke Sjoberg

\section{Paper I}

Study design:

Data collection:

Analysis:

Interpretation:

Writing:

Revision:

\section{Paper II}

Study design:

Data collection:

Analysis:

Interpretation:

Writing:

Revision:

\section{Paper III}

Study design:

Data collection:

Analysis:

Interpretation:

Writing:

Revision:

\section{Paper IV}

Study design:

Data collection:

Analysis:

Interpretation:

Writing:

Revision:
DB, IS, FS

DB

$\mathrm{DB}, \mathrm{MF}$

DB, RG, RL, FS

DB, RL, IS; FS

DB, RL, RG, IS, FS

\author{
RL, FS \\ RL \\ RL, MF, SW \\ RL, MF, SW, IS, RG, FS \\ RL, IS, RG, FS \\ RL, MF, IS, RG, SW, FS
}

RL, FS

RL

RL, MF

RL, DB, MF, IS, RG, FS

RL, DB, IS, RG, FS

RL, DB, MF, IS, RG, FS 


\section{POPULÄRVETENSKAPLIG SAMMANFATTNING PÅ SVENSKA}

\section{Bakgrund}

En av de vanligaste globala dödsorsakerna är skador. Enbart i EU vårdas mer än 40 miljoner människor per år på sjukhus för olika typer av skador, och $7 \%$ procent av alla dödsfall i Sverige är orsakade av skador. I Skandinavien är trubbigt våld är den vanligaste skademekanismen. Det vanligaste är att döden inträffar innan patienten kommer till sjukhuset, sk "prehospital dödlighet". Några anledningar till hög prehospital dödlighet är: stora glesbygdsområden, långa transporttider, lång tid till larm och dödliga skador. Bland de patienter som överlevt fram till sjukhus kan de dödligaste skadorna delas in i tre huvudgrupper med olika skademekanismer: fallskador, trafikskador och övergreppsrelaterade skador. Denna avhandling fokuserar till största delen på de patienter som kommit till sjukhus och blivit inskrivna för vidare vård, undantaget artikel I.

\section{Register och riskjustering}

Denna avhandling baseras på stora registerstudier, dvs analyser på redan insamlat data (från slutenvårdsregistret och dödsorsaksregistret). För att undersöka ett område (i denna avhandling skador) där det är svårt eller omöjligt att utföra randomiserade prospektiva studier är registerstudier ett välbeprövat alternativ. De stora mängderna insamlat data innebär även att olika sjukhus eller olika grupper kan jämföras mot varandra.

Att enbart jämföra icke justerade siffror kan leda till felaktiga tolkningar. För att det ska vara meningsfullt att jämföra olika resultat behövs ett system för att justera (jämka) risken för att dö mellan olika skador, dvs riskjustering. Efter utförd riskjustering finns flera fallgropar kvar. En av de största är att missta samband (faktor x hör samman med effekten) för orsak (faktor y leder till effekten). En annan är att tro att data på gruppnivå går att applicera på enskilda patienter. Riskjusterade data är gjorda för att jämföra patientgrupper med varandra.

Det finns ingen idealmodell för riskjustering men ISS (Injury Severity Score) och ICISS (International Classification of disease Injury Severity Score) är två vanligt förekommande. I denna avhandling används ICISS eftersom den är mindre subjektiv och kan inkludera fler skador än ISS. Efter att riskjusteringen för själva skadorna är gjord, finns flertalet andra faktorer som också påverkar dödligheten i ett trauma; antalet skador, fysiologiskt grundstatus (där ålder ofta används som en pseudomarkör), kön, samsjuklighet (komorbiditet), komplikationer vid behandlingar, rehabiliteringsförmåga etc.

Det finns flera möjliga mätpunkter för att utvärdera skadeutfall. Denna avhandling har 30-dagars dödlighet (död som inträffar inom 30 dagar efter ankomst till sjukhus) som primär mätpunkt för den riskjusterade delen. 


\section{Samband eller orsak?}

Som tidigare nämnts är det viktigt att skilja på samband och orsak. Den här avhandlingen beskriver primärt samband, men det är intressant att fundera på om sambanden gemensamt kan peka mot en orsak. En ofta använd niopunktslista för att analysera samband och orsak är "Hills kriterier", publicerad redan 1965:

1. Statistisk styrka i sambandet?

2. Går sambandet att upprepa av någon annan?

3. Hur pass väl förutspår en variabel en annan?

4. Föregår sambandet effekten (dvs inträffade skadan innan död)?

5. Går det att hitta vilken dos som ger effekt? Gärna med en gradient.

6. Finns det en biologisk förklaring för sambandet?

7. Går sambandet i linje med redan existerande teorier?

8. Kan effekten bli modifierad om sambandet ändras?

9. Finns det någon annan mer logiskt förklaring eller något annat mer passande samband?

Även om alla dessa frågor är besvarade finns inget säkert test som utvärderar om ett samband är en orsak eller inte. Fyrtio år senare publicerade Lucas kompletterande punkter för att utvärdera icke-experimentella studier där stor vikt låg vid felkällor och hur man skulle filtrera bort brus ur mätmetoder. Det finns olika typer av felkällor: slumpmässiga fel (error), systematiska fel (bias) och logiska eller förvirrande fel (confounders). Alla dessa felkällor bör minimeras innan sambanden kan tolkas som en orsak.

\section{Syfte med avhandlingen}

Det generella syftet med denna avhandling var att undersöka skaderelaterad dödlighet mellan 2001 till 2011 i de tre allvarligaste skadekategorierna: fall, trafik och övergreppsrelaterade skador med ICISS som riskjusteringsmodell i material hämtat från Slutenvårdsregistret och Dödsorsaksregistret.

Mer specifikt undersöks:

- Förändringar över tid.

- Hur ICISS-modellen förändras när komorbiditet $i$ form av Charlsons Comorbiditets Index (CCI) adderas till en grundmodell bestående av ICISS, ålder och kön.

- Varför kvinnligt kön ger en överlevnadsfördel vid svåra skador (med utgångspunkt från de två teorierna hormonellt eller genetiskt).

\section{Metoder}

Slutenvårdsregistret och dödsorsaksregistret kombinerades med hjälp av personnummer för datauttag.

\section{Artikel 1}

Alla i Sverige som dött med en skada som trolig orsak från 1999 till 2012 användes i artikel I, där skadorna via ICD-10 systemet konverterades till mekanismer. Slutenvårdsregistret användes för att dela upp dödsfallen i två grupper: prehospital 
dödlighet och död som inträffat efter ankomst till sjukhus. Dessa grupper analyserades sedan via sin skademekanism normerat till död/100 000 person-år och åldersgrupperades.

\section{Artikel 2 till 4}

Alla sjukhusinläggningar mellan 2001 till 2011 som bedömdes vara pga en skada användes för att bygga en databas. Vidare analyser gjordes för grupperna fall-, trafik- och övergreppsrelaterade skador. Uppgifter om skadan, inläggningsdatum, ålder, kön och komorbiditet samlades in och användes i de olika artiklarna. För den fjärde artikeln användes ålderskategorier för att dela in kvinnorna i presumtiva hormonnivåer (före menstruation, fertila kvinnor, efter menopaus).

\section{Skadejustering och andra metoder för att riskjustera}

För att justera för skador kan man använda antingen anatomiska eller fysiologiska markörer. I denna avhandling användes de anatomiska. Som justeringsmodell användes International Classification of disease Injury Severity Score (ICISS). I ICISS tar man först proportionerna överlevare i varje skada (kallat DSP, den Diagnos-Specifika sannolikheten för att överleva skadan) och multiplicerar sedan ihop samtliga DSPer. Summan blir ICISS, ett överlevnadsmått som kan översättas i procent. Dvs 1,0 är en hundraprocentig överlevnad och 0,0 är ingen överlevnad alls. En fingerad patient som blivit bränd och knivhuggen används här som räkneexempel: traumatisk chock (DSP 0,590), multipla skador på kärl i buken (DSP 0,706), 72\% brännskador (DSP 0,455) och till sist en inhalationsskada (DSP 0,677). ICISS-värdet blir då: $(0,59 \times 0,706 \times 0,455 \times$ $0,677)=0,128$. Dvs en överlevnadschans på $13 \%$.

För analyserna på de riskjusterade skadorna i denna avhandling användes förutom ICISS, ålder, kön och komorbiditet. I artikel III användes även tid. Både linjära och logaritmiska regressioner samt statistiska tester användes för att kontrollera skillnad mellan olika undergrupper. Kontroll av modellens precision, kalibrering och diskrimination gjordes $\mathrm{i}$ artikel II.

\section{Resultat och slutsatser}

I artikel I upprepades den "vedertagna sanningen" att $2 / 3$ av trauma är män, men i data för artikel II till IV var det bara ca 45\% män. När data sedan justerades till de skadorna med $15 \%$ dödlighet (internationellt sett allvarliga skador, ICISS 0.85 ) så var $57 \%$ män. För att få en jämförbar siffra (2/3) så var det tvunget att titta på de skador som hade en beräknad dödlighet på 25\% (ICISS 0.75 ), se Tabell 5 .

En annan sak som utmärkte sig i artikel II till IV var att patienterna var förhållandevis friska (90\% var utan komorbiditet). Delat på grupper var det tydligt att de som drabbats av fallrelaterade skador hade flest komorbiditeter (Tabell 6). Komorbiditetens effekt på predicerad 30-dagarsdödlighet undersöktes noggrannare i artikel II. Modellen blev bättre om man lade till komorbiditet till ICISS, kön och ålder.

Artikel III visade en minskning i riskjusterad 30-dagars dödlighet över tid för trafik och övergrepp (OR 0,95 med $\mathrm{p}<0,001$ samt OR 0,93 med $\mathrm{p}=0,008$ ). Ingen minskning kunde visas i fallgruppen. Detta ger stora effekter över tid då OR är per år. En minskning på 5\% per år ger en minskning på $43 \%$ över hela perioden (trafikrelaterade skador) och följaktligen ger en minskning på $7 \%$ en sammanlagd minskning på $55 \%$ under perioden (övergreppsrelaterade skador). 
Ojusterade data visade att antalet fall- och trafikrelaterade skador minskade över tid (koefficient $-4,71$ med $\mathrm{p}=0,047$ och koefficient $-5,37$ med $\mathrm{p}<0,001$ ) medan övergreppsrelaterade skador förblev desamma över tid. Detta står i motsättning till artikel I där fall-relaterade skador ökade över tid med en koefficient på $0,34(p<0,001)$ medan både trafik och övergreppsrelaterade skador minskade (koefficient $-0,27, \mathrm{p}<0,001$ och koefficient $-0,03, \mathrm{p}=0,006)$.

När riskjusterade data jämfördes med ålder sågs en exponentiell ökning av den riskjusterade 30-dagarsdödligheten med ökande ålder (se Figur 6).

I artikel I (ojusterade data) sågs en tydlig minskad dödlighet över tid för män i arbetsför ålder (koefficient $-0,54, p=0,015$ ). Det sågs inte någon motsvarande fördel för kvinnor $\mathrm{i}$ arbetsför ålder. I den riskjusterade gruppen (artikel III) sågs en minskad dödlighet för hela studiegruppen över tid. När kvinnor och män analyserades separat sågs inte någon signifikant minskning för kvinnor även om trenden fanns där.

Den kvinnliga överlevnadsfördelen jämfört med män var tydlig och genomgående i den riskjusterade gruppen (artikel II-IV). Tidigare har det framkommit teorier att det skulle bero på en skyddande effekt av östrogen. I artikel IV sågs en kvinnlig överlevnadsfördel med ökande ålder, vilket inte talar för ett hormonellt skydd av östrogen.

\section{Diskussion}

I artikel I sågs en prehospital dödlighet på mer än 3/4, i enlighet med vad som tidigare visats i Skandinavien. Detta pekar på att prevention och prehospital behandling bör vara en fokuspunkt i framtiden. Den höga prehospitala dödligheten kan vara ett uttryck för att det inte finns något nationellt organiserat system för läkare prehospitalt.

Ett annat intressant fynd var att den prehospitala dödligheten i arbetsför ålder minskade över tid, primärt bland män. Detta har tidigare setts tex för brännskador. Sammantaget kan detta tolkas som att mäns risktagande beteende långsamt förändras av samhället i stort.

Det mest använda systemet för att riskjustera skador är ISS, som dock har några stora nackdelar. I huvudsak innebär systemet att speciellt utbildade poängsättare subjektivt graderar skador efter vilka som är "värst". De tre värsta skadorna i olika kroppsregioner poängsätts, kvadreras, samt räknas sedan ihop till en poängsumma mellan 1 och 75 . Detta kräver extra utbildning och innebär dessutom ett separat spår som är skiljt från kliniken. Förutom svagheten med en subjektiv metod innebär detta att när sjukvårdens resurser knappt räcker till kärnverksamheten blir det eftersatt att poängsätta trauman.

Ovanstående är några av de argument som Osler förde fram 1996 när han byggde ICISS. ICISS har sedan bevisats fungera minst lika bra som ISS på de administrativa data som genereras på sjukhusen. Den svenska registerkulturen lämpar sig bra för ICISS och det är gjort flertalet studier inom det svenska systemet som visar utmärkta resultat.

I artikel II, utvecklades Oslers metod vidare, då han inte justerade för ålder, kön och komorbiditet. Tidigare svenska arbeten har justerat för ålder och kön men inte komorbiditet. I den här avhandlingen utvärderades effekten av komorbiditet på modellen avseende precision, kalibrering och diskriminering. För att testa metoden användes de svåraste skadorna i svensk slutenvård (fallrelaterat, trafikrelaterat, övergreppsrelaterat). 
Den riskjusterade 30-dagars dödligheten utvärderades i artikel III från ett tidsperspektiv, där justerade data från ett decennium jämfördes för att kunna upptäcka förbättringar $i$ vården. Resultaten visade att vården förbättrats angående trafik- och övergreppsrelaterade skador men inte för fallrelaterade skador. Kumulativt var det en skillnad på upp till $55 \%$ mellan första och sista året. Riskjusteringen innebär att vi kan vara säkra på att skadepanoramat inte spelar in i detta.

Den mest troliga orsaken till att fallrelaterade skador inte förbättrats över tid är förmodligen att de inte åtnjutit samma exponering i tex "traumakurser" och forskning som trafik- och övergreppsrelaterade skador. Detta till trots så är fallolyckor ett folkhälsoproblem som förmodligen kommer att öka $i$ framtiden med en åldrande befolkning.

Fallrelaterade skador är också svåra att kvantifiera. Det som visade sig vara svårast att kvantifiera inom fallgruppen var "fall från annat plan" (som det står i ICD-10 beskrivningen) vilket vid närmare efterforskning sträckte sig från fall ur flygplan till fall nerför (ospecificerat antal) trappsteg. I övrigt är gruppen fall från annat plan lik fallgruppen i stort, förutom att nästan 5\% var spädbarn (d.v.s. inte fyllda ett år ännu).

Fallrelaterade skador är kanske en av de mer spännande delarna av denna avhandling och i retrospektroskopet hade de förtjänat en egen avhandling.

Sista artikeln (artikel IV) undersöker varför det finns en kvinnlig överlevnadsfördel vid trauma. Något stöd för att östrogen skulle vara ett skyddande hormon kunde inte hittas. Detta är intressant och bör undersökas vidare, eftersom tidigare studier visat att män erhåller mer intensivvård än kvinnor, men ändå inte har någon överlevnadsfördel.

Slutligen undersöks i avhandlingen hur starka indicier det finns för att sambanden kan vara orsaker (se Tabell 11). Sammanfattningsvis verkar det troligt att skadorna är orsaker till död, men det kan inte uteslutas att det bara är samband. Data är solida och stämmer väl överens med det tidigare publicerade material i Skandinavien. ICISS, kön, ålder och komorbiditet förklarar en stor del av den förutspådda 30-dagars dödligheten.

\section{Slutsatser}

I fortsättningen bör trauma utvärderas både justerat och ojusterat, prehospitalt och inhospitalt för att få en vidgat perspektiv på skadepanoramat och skadeepidemiologin med 30-dagars dödlighet. De svenska registren fungerar utmärkt tillsammans med ICISS för att justera för skadorna, men ålder, kön och komorbiditet bör inkluderas i analyserna. Den kvinnliga överlevnadsfördelen ökade med ökande ålder, vilket motsäger teorin att östrogen skulle vara ett skyddande hormon. 


\section{ACKNOWLEDGEMENTS}

Trying to name all the people that helped, inspired, coaxed, tricked, flattered, teased or in any other way made me go that extra mile (a lot of miles when you add them up) would only result in an everlasting list that probably wouldn't be complete regardless of the effort I would put in.

However, I would like to name some of you:

Folke Sjöberg, for being not only my main supervisor and dragging me out the trenches I keep on digging for myself, but also for being the permanent optimist. Without your expert knowledge of the scientific process my research career would have been short and not especially sweet. I wish that I only had one percentage of your social mingling skills, but I am grateful for all the things you transferred to me (willingly or unwillingly) and not only in the field of research. Thank you for opening the doors to the scientific community!

Ingrid Steinvall, your help is beyond a few rows in a thesis, it's priceless. The first time I sat down at your desk it was for the help with Excel ${ }^{\circledR}$, all the other times it was to get your know-how and the discussions that dragged out in long evenings after light faded away. The robustness of your "I do not understand, explain it in another way..." is admirable and something I will always carry with me in my further research.

Denise Bäckström, for being a friend and a colleague both around the clock and around the world. You are truly remarkable, I don't know anyone else that has the ability to spin a descent idea into a great one, whilst looking effortless.

Mats Fredriksson, your help in the statistic department was phenomenal. The many hours at your desk have incorporated knowledge in me, sometimes even without me noticing. When people ask about this thesis and I tell them that it is: "mainly mathematical models of epidemiological mortality models based on registry data", you are the one who tricked me into believing that it's all fairly basic.

Rolf Gedeborg, apart from helping me write and giving me a much-needed perspective. I would like to thank you for being a good discussion partner in statistics, methodology and writing.

Sten Walther, thank you for being generous both with knowledge, working time and scripts for Stata ${ }^{\circledR}$. I have learned astray that scripts is holier than the recipe for grandmothers' meatballs.

Fredrik Iredahl for being junior but still marking the route.

Ferenc Sari, all the things you have done for me is beyond belief. You where there when I took my first steps in anaesthesia and critical care. Your trust and patience will for ever be the golden standard when teaching or discussing with medical juniors.

Linköping University and all the staff that I have encountered during my PhD-studies. Thank you for helping me to see the scientific world in an organized perspective and for pointing out what should have been obvious in all the courses and proceedings. I would 
like to direct a special thanks to Michelle Chew for giving me a new and extended perspective on research and being a good discussion partner. Many of the things I have done would not be possible without your help.

All my co-workers and colleagues at my department; AnOpIVA. My eternal thanks for letting me do this, without your support it would have been impossible. A special thanks to the current and former directors and supervisors for believing in my research. Thank you Anna Oscarsson Tibblin, director and role-model for being a clinician and active researcher at the same time, and for teaching me what research is all about in a gloomy corridor a morning when my energy was completely depleted.

To my co-workers at KMC, your never-ending positive boost of my work still blows me away. Thank you for listening, taking me in and making me part of your work.

To MRT for your support and being a part of it all, without treating me any different.

To my friends, I look forward to spending more time with you all, and doing all of the crazy plans we made during my PhD-time. This is a hard part to write, because you are many and when I think back on the time doing the $\mathrm{PhD}$ you are so important. I will not mention you all, but you are in my thoughts. To Christopher for being the biggest optimist I know, it has helped me more than you can believe. To Carnis for curling me and sweeping my way mentally and for actually dragging me out to play in the good (and bad weather). I hope you'll all join me for a silent toast in the festivities. To Kåre, Stefan, Martina and Martin for being there when it started a long time ago and making Linköping a good place to live, and for the marvellous wedding gift displayed on the cover. An extra thanks to you Martin; you are one of the most academic hostile people I know but I know that you always got my back. You are one of my best (and most used) pressure valves.

All of you that asked me if you could help, and actually did help, was a tremendous off-load that I needed to keep the small amounts of mental health that I still got left.

A big part of me being able to do this is because of the help I have got (and still getting) from my family (both by blood and by chosing).

Mother, thank you for being my longest supporter. You have shown me the way countless times in my life and still does even though I hardly notice the new directions before the moment to thank you has passed.

Father, I have a lot of things to thank you for. Thank you for making me understand that I need to be the change in life that I want to see.

Anna, even though I didn't tell you, you helped me a lot when I was younger. Thank you for helping me to become the man I am. Sometimes the ones walking behind you is as important as those walking in front of you. I am actually glad that you're still a part of my life (even though all the fighting we did when we were younger) and I hope we will continue developing our relationship further now.

Kai, you are the one relative that relentlessly been asking me to read my new manuscript, debating morale and ethics by the kitchen table, simultaneously maintaining that you're not an influencer in my life. Guess what? You are.

Vidar, for showing me what's important in life. I am longing to spend more time with you. Thank you for the precious moments of "non-research-time" and for the most 
magical ways to express trust and relaxation. Your small, careful "nosings" will be remembered fondly and warms my heart.

The last person that I want to name is not the person that deserves it the least, au contraire: Hanna, my love, my wife. Thank you for letting me do this, even though it been rough on us both. Since we met we have always helped and supported each other. You have done more than that; above and beyond is just the introduction. It would have been impossible to do this without your encouragement, your support, your loving care, your presence.

You are the song in my heart and I am looking forward to singing duets with you again. Singing solo, even if we're in the same room, is exhausting and insipid.

I can lead but I need you. Dance with me?

It is not a bias, it is a prerequisite and a heartful and extended thanks; to the Linköping University, the County of Östergötland and The Carnegie found for helping me funding the research and this thesis. 


\section{REFERENCES}

1. Alberdi F, Garcia I, Atutxa L, Zabarte M, Semicyuc T. Epidemiology of severe trauma. Med Intensiva (English Edition). 2014;38(9):580-588.

2. World Health Organization, Regional Office for Europe. The European Health Report 2012. Charting the Way to Well-Being. 2013:1-161.

3. Søreide K, Krüger AJ, Vårdal AL, Ellingsen CL, Søreide E, Lossius HM. Epidemiology and Contemporary Patterns of Trauma Deaths: Changing Place, Similar Pace, Older Face. World J Surg. 2007;31(11):2092-2103.

4. Wisborg T, Hoylo T, Siem G. Death after injury in rural Norway: high rate of mortality and prehospital death. Acta Anaesthesiol Scand. 2003;47(2):153-156.

5. Kristiansen T, Lossius HM, Rehn M, et al. Epidemiology of trauma: A populationbased study of geographical risk factors for injury deaths in the working-age population of Norway. Injury. 2014;45(1):23-30.

6. Bäckström D, Larsen R, Steinvall I, Fredrikson M, Gedeborg R, Sjöberg F. Deaths caused by injury among people of working age (18-64) are decreasing, while those among older people (64+) are increasing. Eur J Trauma Emerg Surg. 2018;44(4):589-596.

7. Raatiniemi L, Steinvik T, Liisanantti J, et al. Fatal injuries in rural and urban areas in northern Finland: a 5-year retrospective study. Acta Anaesthesiol Scand. 2016;60(5):668-676.

8. Peek-Asa C, Zwerling C, Stallones L. Acute Traumatic Injuries in Rural Populations. Am J Public Health. 2011;94(10):1689-1693.

9. Gedeborg R, Chen L-H, Thiblin I, et al. Prehospital injury deaths - Strengthening the case for prevention. J Trauma Acute Care Surg. 2012;72(3):765-772.

10. Statistics Sweden. Population by age and sex. http://www.statistikdatabasen.scb.se/pxweb/en/ssd/START_BE_BE0101_BE 0101A/BefolkningR1860/?rxid=3858e946-350b-40e0-bf56-f21a52a9562d. Accessed June 3, 2016.

11. Ludvigsson JF, Otterblad-Olausson P, Pettersson BU, Ekbom A. The Swedish personal identity number: possibilities and pitfalls in healthcare and medical research. Eur J Epidemiol. 2009;24(11):659-667.

12. Ringdal $\mathrm{KG}$, Coats $\mathrm{TJ}$, Lefering $\mathrm{R}$, et al. The Utstein template for uniform reporting of data following major trauma: a joint revision by SCANTEM, TARN, DGU-TR and RITG. Scand J Trauma Resusc Emerg Med. 2008;16(1):7.

13. Dick WF, Baskett PJ. Recommendations for uniform reporting of data following major trauma--the Utstein style. A report of a working party of the International Trauma Anaesthesia and Critical Care Society (ITACCS). Resuscitation. 1999;42(2):81-100. 
14. Ghorbani P, n MF, Riddez L, f MS, Oldner A, mmer LS. Clinical review is essential to evaluate 30-day mortality after trauma. Scand J Trauma Resusc Emerg Med. 2014;22(1):1-7.

15. Bøtker MT, Bakke SA, Christensen EF. A systematic review of controlled studies: do physicians increase survival with prehospital treatment? Scand J Trauma Resusc Emerg Med. 2009;17(1):12-18.

16. Haagsma JA, Graetz N, Bolliger I, et al. The global burden of injury: incidence, mortality, disability-adjusted life years and time trends from the Global Burden of Disease study 2013. Inj Prev. 2015;22(1):3-18.

17. Orwelius L, Bergkvist M, Nordlund A, et al. Physical Effects of the Trauma and Psychological Consequences of Preexisting Diseases Account for a Significant Portion of the Health-Related Quality of Life Pattern of Former Trauma Patients. J Trauma Acute Care Surg. 2012;72(2):504-12.

18. Orwelius L, Willebrand M, Gerdin B, Ekselius L, Fredrikson M, Sjöberg F. Long term health-related quality of life after burns is strongly dependent on pre-existing disease and psychosocial issues and less due to the burn itself. Burns. 2013;39(2):229-235.

19. Kehoe A, Smith JE, Edwards A, Yates D, Lecky F. The changing face of major trauma in the UK. Emerg Med J. 2015;32(12):911-915.

20. Labib N, Nouh T, Winocour S, et al. Severely Injured Geriatric Population: Morbidity, Mortality, and Risk Factors. J Trauma Acute Care Surg. 2011;71(6):1908-1914.

21. Lehmann R, Beekley A, Casey L, Salim A, Martin M. The impact of advanced age on trauma triage decisions and outcomes: a statewide analysis. Am J Surg. 2009;197(5):571-4-discussion574-5.

22. Meisler R, Thomsen AB, Theilade $\mathrm{P}$, et al. Age-related differences in mechanism, cause, and location of trauma deaths. Minerva Anestesiol. 2011;77(6):592-597.

23. Sjögren $\mathrm{H}$, Björnstig U. Unintentional injuries among elderly people: Incidence, causes, severity, and costs. Accid Anal Prev. 1989;21(3):233-242.

24. Rau C-S, Lin T-S, Wu S-C, et al. Geriatric hospitalizations in fall-related injuries. Scand J Trauma Resusc Emerg Med. 2014;22(1):63.

25. Cothren CC, Moore EE, Hedegaard HB, Meng K. Epidemiology of Urban Trauma Deaths: A Comprehensive Reassessment 10 Years Later. World J Surg. 2007;31(7):1507-1511.

26. World Health Organization. World Report on Road Traffic Injury Prevention. Geneva: World Health Organization; 2004.

27. Ioannidis JPA. The Proposal to Lower P-Value Thresholds to .005. JAMA. 2018;319(14):1429-2. 
28. Greenland S, Senn SJ, Rothman KJ, of JCEJ, 2016. Statistical tests, P values, confidence intervals, and power: a guide to misinterpretations. Eur J Epidemiol. 2016;31(4):337-50.

29. Porta M(ed), Greenland S, Hernán M, Santos Silva dos I. A Dictionary of Epidemiology. Sixth edition. New York: Oxford University Press; 2014.

30. Hill AB. The environment and disease: association or causation? Proc Royal Soc Med. 1965:295-300.

31. Lucas RM, McMichael AJ. Association or Causation: Evaluating Links Between "Environment and Disease". Bull World Health Organ. 2005;83(10):792-795.

32. Larsen R, Bäckström D, Fredrikson M, Steinvall I, Gedeborg R, Sjöberg F. Decreased risk adjusted 30-day mortality for hospital admitted injuries: a multicentre longitudinal study. Scand J Trauma Resusc Emerg Med. 2018;26(1):24.

33. Fournier A, Weiderpass E. Characteristics and recent evolution of menopausal hormone therapy use in a cohort of Swedish women. Climacteric. 2009;12(5):410418.

34. Moreno RP, Metnitz PGH, Almeida E, et al. SAPS 3-From evaluation of the patient to evaluation of the intensive care unit. Part 2: Development of a prognostic model for hospital mortality at ICU admission. Intensive Care Med. 2005;31(10):1345-1355.

35. Knaus WA, Draper EA, Wagner DP, Zimmerman JE. APACHE II: a severity of disease classification system. Crit Care Med. 1985;13(10):818-829.

36. Apgar V. A Proposal for a New Method of Evaluation of the Newborn Infant. Originally Published in July 1953, Volume 32, Pages 250-259. Anesth Analg. 2015;120(5):1056-1059.

37. Champion HR, Sacco WJ, Carnazzo AJ, Copes W, Fouty WJ. Trauma score. Crit Care Med. 1981;9(9):672-676.

38. Boyd CR, Tolson MA, Copes WS. Evaluating trauma care: the TRISS method. Trauma Score and the Injury Severity Score. J Trauma. 1987;27(4):370-378.

39. Skaga NO, Eken T, Søvik S. Validating performance of TRISS, TARN and NORMIT survival prediction models in a Norwegian trauma population. Acta Anaesthesiol Scand. 2018;62(2):253-266.

40. Ringdal KG, Skaga NO, Hestnes M, et al. Abbreviated Injury Scale: Not a reliable basis for summation of injury severity in trauma facilities? Injury. 2013;44(5):691699.

41. Abbreviated injury scale. Injury. 1982;14(1):107.

42. MacKenzie EJ, Shapiro S, Eastham JN. The Abbreviated Injury Scale and Injury Severity Score. Levels of inter- and intrarater reliability. Medical Care. 1985;23(6):823-835. 
43. Baker SP, O'Neill B, Haddon W, Long WB. The injury severity score: a method for describing patients with multiple injuries and evaluating emergency care. $J$ Trauma. 1974;14(3):187-196.

44. Palmer CS, Gabbe BJ, Cameron PA. Defining major trauma using the 2008 Abbreviated Injury Scale. Injury. 2016;47(1):109-115.

45. Osler T, Baker SP, Long W. A modification of the injury severity score that both improves accuracy and simplifies scoring. J Trauma. 1997;43(6):922-5discussion925-6.

46. Osler T, Rutledge R, Deis J, Bedrick E. ICISS: an international classification of disease-9 based injury severity score. J Trauma. 1996;41(3):380-6discussion386-8.

47. Rutledge R, Osler T, Emery S, Kromhout-Schiro S. The end of the Injury Severity Score (ISS) and the Trauma and Injury Severity Score (TRISS): ICISS, an International Classification of Diseases, ninth revision-based prediction tool, outperforms both ISS and TRISS as predictors of trauma patient survival, hospital charges, and hospital length of stay. J Trauma. 1998;44(1):41-49.

48. Gagné M, Moore L, Beaudoin C, Batomen Kuimi BL, Sirois M-J. Performance of International Classification of Diseases-based injury severity measures used to predict in-hospital mortality: A systematic review and meta-analysis. J Trauma Acute Care Surg. 2016;80(3):419-426.

49. Kim Y, Jung KY, Kim CY, Kim YI, Shin Y. Validation of the International Classification of Diseases 10th Edition-based Injury Severity Score (ICISS). $J$ Trauma. 2000;48(2):280-285.

50. Stephenson S, Henley G, Harrison JE, Langley JD. Diagnosis based injury severity scaling: investigation of a method using Australian and New Zealand hospitalisations. Inj Prev. 2004;10(6):379-383.

51. Tohira H, Jacobs I, Mountain D, Gibson N, Yeo A. Systematic review of predictive performance of injury severity scoring tools. Scand J Trauma Resusc Emerg Med. 2012;20(1):63.

52. Leaphart CL, Graham D, Pieper P, Celso BG, Tepas JJ. Surgical quality improvement: a simplified method to apply national standards to pediatric trauma care. J Pediatr Surg. 2009;44(1):156-159.

53. Kilgo PD, Meredith JW, Hensberry R, Osler TM. A note on the disjointed nature of the injury severity score. J Trauma. 2004;57(3):479-85-discussion486-7.

54. Ashley DW, Pracht EE, Medeiros RS, et al. An analysis of the effectiveness of a state trauma system. J Trauma Acute Care Surg. 2015;78(4):706-714.

55. Charlson ME, Pompei P, Ales KL, MacKenzie CR. A new method of classifying prognostic comorbidity in longitudinal studies: development and validation. $J$ Chronic Dis. 1987;40(5):373-383. 
56. Christensen S, Johansen MB, Christiansen CF, Jensen R, Lemeshow S. Comparison of Charlson comorbidity index with SAPS and APACHE scores for prediction of mortality following intensive care. CLEP. 2011;3:203-211.

57. Roberts G, Lloyd M, Parker M, et al. The Baux score is dead. Long live the Baux score: a 27-year retrospective cohort study of mortality at a regional burns service. J Trauma Acute Care Surg. 2012;72(1):251-256.

58. Steinvall I, Elmasry M, Fredrikson M, Sjöberg F. Standardised mortality ratio based on the sum of age and percentage total body surface area burned is an adequate quality indicator in burn care: An exploratory review. Burns. 2016;42(1):28-40.

59. Gomez D, Haas B, de Mestral C, et al. Gender-associated differences in access to trauma center care: A population-based analysis. Surgery. 2012;152(2):179-185.

60. Zhu Z, Shang X, Qi P, Ma S. Sex-based differences in outcomes after severe injury: an analysis of blunt trauma patients in China. Scand J Trauma Resusc Emerg Med. 2017;25(1):47-47.

61. Raju R, Bland KI, Chaudry IH. Estrogen: a novel therapeutic adjunct for the treatment of trauma-hemorrhage-induced immunological alterations. Mol Med. 2008;14(3-4):213-221.

62. Spolarics ZN. The X-Files of Inflammation. Shock. 2007;27(6):597-604.

63. Spolarics Z, Peña G, Qin Y, Donnelly RJ, Livingston DH. Inherent X-Linked Genetic Variability and Cellular Mosaicism Unique to Females Contribute to SexRelated Differences in the Innate Immune Response. Front Immunol. 2017;8:1455.

64. Brier GW. Verification of Forecasts Expressed in Terms of Probability. MWR. 1950;78(1):1-3.

65. Steyerberg EW, Vickers AJ, Cook NR, et al. Assessing the Performance of Prediction Models. Epidemiology. 2010;21(1):128-138.

66. Cox DR. Two further applications of a model for binary regression. Biometrika. 1958;45(3-4):562-565.

67. Kramer AA, Zimmerman JE. Assessing the calibration of mortality benchmarks in critical care: The Hosmer-Lemeshow test revisited. Crit Care Med. 2007;35(9):2052-2056.

68. Greene WH(ed). Econometric. Seventh Edition. London: Pearson Education Limited; 2012.

69. Hosmer DW, Lemeshow S. Applied Logistic Regression. Second Edition. New York: John Wiley and sons, Inc; 2000.

70. Greenberg RS, Daniels SR, Flanders WD, Eley JW, Boring JR III. Medical Epidemiology. Fourth edition. New York: Lange Medical Books, McGraw Hill; 2005. 
71. Pompermaier L, Elmasry M, Abdelrahman I, Fredrikson M, Sjöberg F, Steinvall I. Are there any differences in the provided burn care between men and women? A retrospective study. Burn Trauma. 2018;6(1):1-6.

72. Bakke HK, Wisborg T. Rural High North: A High Rate of Fatal Injury and Prehospital Death. World J Surg. 2011;35(7):1615-1620.

73. Brattström O, Eriksson M, Larsson E, Oldner A. Socio-economic status and comorbidity as risk factors for trauma. Eur J Epidemiol. 2015;30(2):151-157.

74. Hansen KS, Morild I, Engesaeter LB, Viste A. Epidemiology of severely and fatally injured patients in western part of Norway. Scand J Surg. 2004;93(3):198203.

75. Taylor C, Jan S, Curtis K, et al. The cost-effectiveness of physician staffed Helicopter Emergency Medical Service (HEMS) transport to a major trauma centre in NSW, Australia. Injury. 2012;43(11):1843-1849.

76. for the PIM Study Group, Slater A, Shann F, Pearson G. PIM2: a revised version of the Paediatric Index of Mortality. Intensive Care Med. 2003;29(2):278-285.

77. Singletary SE, Greene FL, Sobin LH. Classification of isolated tumor cells. Cancer. 2003;98(12):2740-2741.

78. Bergeron E, Simons R, Linton C, et al. Canadian Benchmarks in Trauma. $J$ Trauma. 2007;62(2):491-497.

79. Stephenson SCR, Langley JD, Civil ID. Comparing measures of injury severity for use with large databases. J Trauma. 2002;53(2):326-332.

80. Davie G, Cryer C, Langley J. Improving the predictive ability of the ICD-based Injury Severity Score. Inj Prev. 2008;14(4):250-255.

81. Gedeborg R, Warner M, Chen L-H, et al. Internationally comparable diagnosisspecific survival probabilities for calculation of the ICD-10-based Injury Severity Score. J Trauma Acute Care Surg. 2014;76(2):358-365.

82. Gedeborg R, Svennblad B, Byberg L, Michaëlsson K, Thiblin I. Prediction of mortality risk in victims of violent crimes. Forensic Sci Int. 2017;281:92-97.

83. Mitchell RJ, Ting HP, Driscoll T, Braithwaite J. Identification and internal validation of models for predicting survival and ICU admission following a traumatic injury. Scand J Trauma Resusc Emerg Med. 2018;26(1):326-11.

84. Jensen J, Lundin-Olsson L, Nyberg L, Gustafson Y. Fall and injury prevention in older people living in residential care facilities. A cluster randomized trial. Ann Intern Med. 2002;136(10):733-741.

85. Bottle A, Aylin P. Mortality associated with delay in operation after hip fracture: observational study. BMJ. 2006;332(7547):947-951.

86. Choudhry MA, Bland KI, Chaudry IH. Trauma and immune response-Effect of gender differences. Injury. 2007;38(12):1382-1391. 
87. Knöferl MW, Angele MK, Diodato MD, et al. Female sex hormones regulate macrophage function after trauma-hemorrhage and prevent increased death rate from subsequent sepsis. Ann Surg. 2002;235(1):105-112.

88. Samuelsson C, Sjöberg F, Karlström G, Nolin T, Walther SM. Gender differences in outcome and use of resources do exist in Swedish intensive care, but to no advantage for women of premenopausal age. Crit Care. 2015;19(1):129.

89. George RL, McGwin G Jr, Metzger J, Chaudry IH, Rue LW III. The Association between Gender and Mortality among Trauma Patients as Modified by Age. $J$ Trauma. 2003;54(3):464-471.

90. Steinvall I, Fredrikson M, Bak Z, Sjöberg F. Mortality After Thermal Injury: No Sex-Related Difference. J Trauma. 2011;70(4):959-964.

91. George RL, McGwin G Jr, Schwacha MG, et al. The Association Between Sex and Mortality Among Burn Patients as Modified by Age. J Burn Care Rehabil. 2005;26(5):416-421.

92. Jneid H, Fonarow GC, Cannon CP, et al. Sex differences in medical care and early death after acute myocardial infarction. Circulation. 2008;118(25):2803-2810.

93. Ulvik A, Wentzel-Larsen T, Flaatten H. Trauma patients in the intensive care unit: short- and long-term survival and predictors of 30-day mortality. Acta Anaesthesiol Scand. 2007;51(2):171-177.

94. Ludvigsson JF, Andersson E, Ekbom A, et al. External review and validation of the Swedish national inpatient register. BMC Public Health. 2011;11(1):450.

95. Bergström MF, Byberg L, Melhus H, Michaëlsson K, Gedeborg R. Extent and consequences of misclassified injury diagnoses in a national hospital discharge registry. Inj Prev. 2011;17(2):108-113.

96. Ala-Kokko TI, Ohtonen P, Koskenkari J, Laurila JJ. Improved outcome after trauma care in university-level intensive care units. Acta Anaesthesiol Scand. 2009;53(10):1251-1256.

97. Nørgaard C, Glud M, Gniadecki R. Are all melanomas dangerous? Acta Derm Venereol. 2011;91(5):499-503.

98. Hörnblad J. Dödsorsaker 2013. Socialstyrelsen; 2015.

99. Celso B, Tepas J, Langland-Orban B, et al. A Systematic Review and MetaAnalysis Comparing Outcome of Severely Injured Patients Treated in Trauma Centers Following the Establishment of Trauma Systems. $J$ Trauma. 2006;60(2):371-378. 


\section{"Cui bono?"}

Carl von Linné, 1752 


\section{ORIGINAL PAPERS}

I. Deaths caused by injury among people of working age (18-64) are decreasing, while those Deaths caused by injury among people of working age (18-64) are decreasing, while those among older people $(64+)$ are increasing. Bäckström D, LARSEN ROBERT, Steinvall I, Fredrikson M, Gedeborg R, Sjoberg F. Eur J Trauma Emerg Surg. 2017; 35(4):278-596.

II. Assessment of risk-adjusted in-hospital injury mortality by ICISS model and the effect of comorbidity. LARSEN ROBERT, Steinvall I, Fredrikson M, Walther S, Gedeborg R, Sjoberg F. In manuscript

III. Decreased risk adjusted 30-day mortality for hospital admitted injuries: a multicenter longitudinal study. LARSEN ROBERT, Bäckström D, Fredrikson M, Steinvall I, Gedeborg R, Sjoberg F. Scand J Trauma Resusc Emerg Med 2018;26(24):1-8.

IV. Female risk-adjusted advantage after injuries caused by falls, traffic or assault: a nationwide 11-year study. LARSEN ROBERT, Bäckström D, Steinvall I, Fredrikson M, Gedeborg R, Sjoberg F. Submitted and under revision 


\section{Papers}

The papers associated with this thesis have been removed for copyright reasons. For more details about these see:

http://urn.kb.se/resolve?urn=urn:nbn:se:liu:diva-154415 


\section{FACULTY OF MEDICINE AND HEALTH SCIENCES}

Linköping University Medical Dissertation No. 1660, 2019

Department of Clinical and Experimental Medicine

Linköping University

SE-581 83 Linköping, Sweden

www.liu.se 